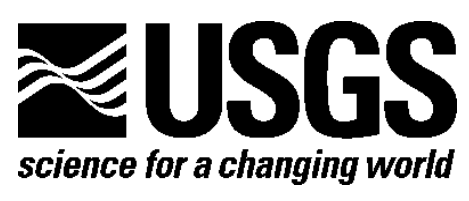

\title{
Faunal and Vegetation Monitoring in Response to Harbor Dredging in the Port of Miami
}

By Andre Daniels, Rachael Stevenson, Erin Smith, and Michael Robblee

Open-File Report 2018-1052

U.S. Department of the Interior

U.S. Geological Survey 


\section{U.S. Department of the Interior \\ RYAN K. ZINKE, Secretary}

\section{U.S. Geological Survey \\ William H. Werkheiser, Deputy Director \\ exercising the authority of the Director}

U.S. Geological Survey, Reston, Virginia: 2018

For more information on the USGS-the Federal source for science about the Earth, its natural and living resources, natural hazards, and the environment-visit https://www.usgs.gov/ or call 1-888-ASK-USGS (1-888-275-8747).

For an overview of USGS information products, including maps, imagery, and publications, visit https://store.usgs.gov/.

Any use of trade, firm, or product names is for descriptive purposes only and does not imply endorsement by the U.S. Government.

Although this information product, for the most part, is in the public domain, it also may contain copyrighted materials as noted in the text. Permission to reproduce copyrighted items must be secured from the copyright owner.

Suggested citation:

Daniels, A., Stevenson, R., Smith, E., and Robblee, M., 2018, Faunal and vegetation monitoring in response to harbor dredging in the Port of Miami: U.S. Geological Survey Open-File Report 2018-1052, 38 p., https://doi.org/10.3133/ofr20181052.

ISSN 2331-1258 (online) 


\section{Acknowledgments}

We would like to thank Nova Southeastern University Halmos College of Natural Sciences and Oceanography for use of research facilities. We thank the following Nova Southeastern University research students that participated in the study with field collections and laboratory work, including Candace Grimes, Elizabeth Colhoun, David Roche, and Emily Powell as well as Jessica Lee and Ross Boucek from Florida International University (FIU). We thank Howard Jelks of USGS, Dr. Chris Blanar of NOVA Southeastern University, and Brian Smith with Cherokee Nation Technologies for their help with PRIMER 7 analysis and graphics in $\mathrm{R}$ statistical computing. We also thank Miami-Dade County Division of Environmental Resources Management (DERM) for their continued support. Finally, a special thanks to Joan Browder of the National Oceanic and Atmospheric Administration for her lifetime of commitment in preserving southern Florida's seagrass communities. All work was conducted under sampling permit SAL-14-1584-SR from the Florida Fish and Wildlife Conservation Commission. 


\section{Contents}

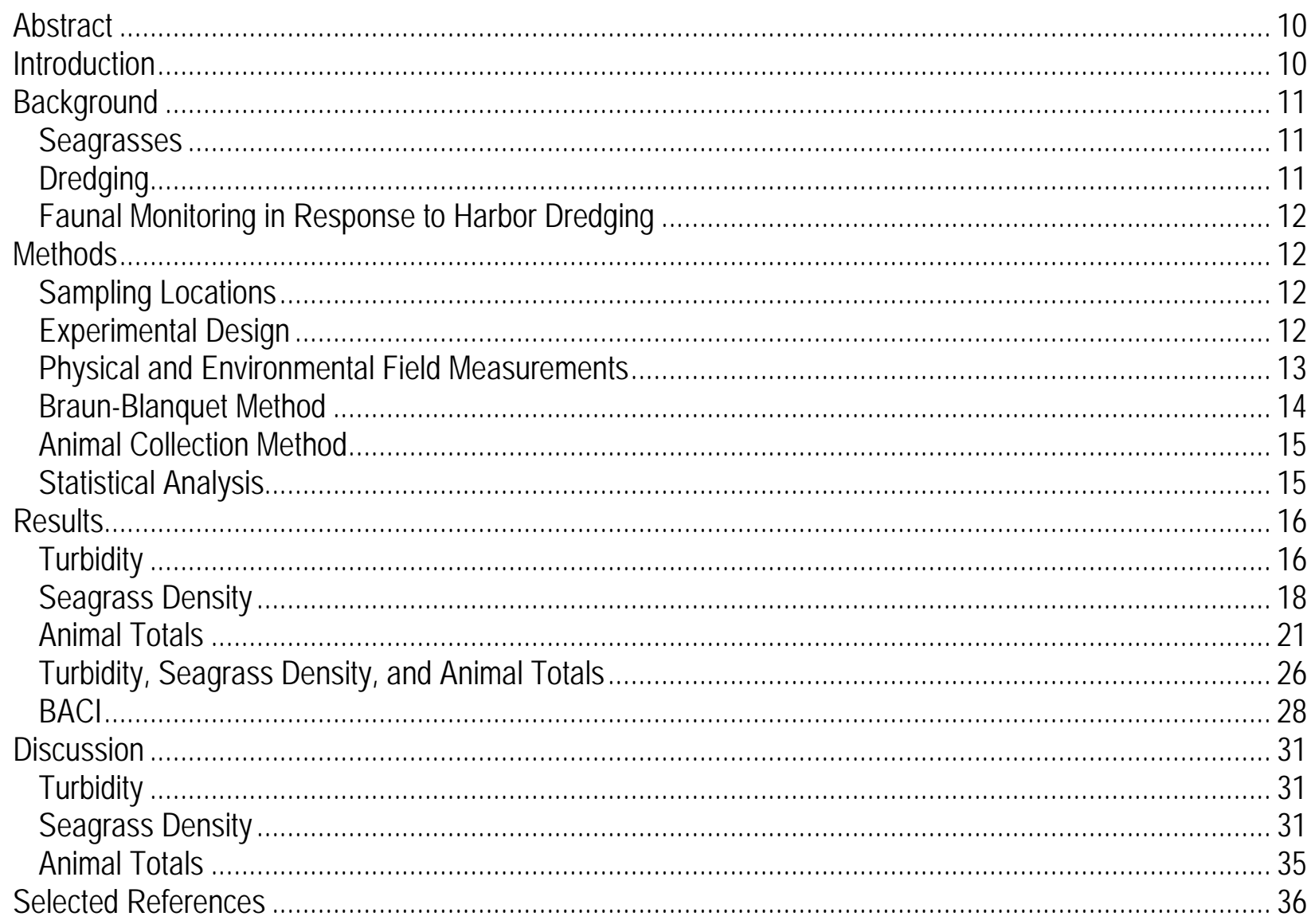

\section{Figures}

Figure 1. Google Earth image of study areas (left) with both basins outlined in red. The top area is North Biscayne Bay (NBB) and the bottom area is Port of Miami (POM). A map of Biscayne Bay (right) showing the 30 cells in each of the two sampling grids for North Biscayne Bay (white) and Port of Miami (green). $\quad 13$

Figure 2. Location of Braun-Blanquet replicate habitat samples in relation to the anchored boat and throw-trap. 14

Figure 3. Boxplots displaying turbidity values (in nephelometric turbidity units [NTUs]) in North Biscayne Bay (NBB) and Port of Miami (POM) in A, each sampling year throughout Fish and Invertebrate Assessment Network (FIAN) and Faunal Monitoring in Response to Harbor Dredging (FMHD), B, each year 
of the FMHD study (2014-2016) in each of the two study areas, and C, each basin by season (wet or dry) in all years of the FMHD study. The box represents the 25 to $75 \%$ interquartile range of values, the bold horizontal line inside the box represents the median value, the upper dashed line represents the maximum value of the third quartile plus 1.5 times the interquartile range, the lower dashed line is the minimum value of the first quartile minus 1.5 times the interquartile range, and circles are outliers. No overlap in the interquartile boxes indicates a significant difference, overlap in the interquartile boxes but not the medians indicates a likely significant difference, overlap in the interquartile boxes and the medians suggests no significant difference....... 18

Figure 4. Boxplots displaying differences in average seagrass densities using the Braun-Blanquet (1965) scale in North Biscayne Bay (NBB) and Port of Miami (POM) in A, each sampling year throughout Fish and Invertebrate Assessment Network (FIAN) and Faunal Monitoring in Response to Harbor Dredging (FMHD), B, each year of the FMHD study (2014-2016) in each of the two study areas, and C, each basin by season (wet or dry) in all years of the FMHD study. The box represents the 25 to 75 percent interquartile range of values, the bold horizontal line inside the box represents the median value, the upper dashed line represents the maximum value of the third quartile plus 1.5 times the interquartile range, the lower dashed line is the minimum value of the first quartile minus 1.5 times the interquartile range, and circles are outliers. No overlap in the interquartile boxes indicates a significant difference, overlap in the interquartile boxes but not the medians indicates a likely significant difference, overlap in the interquartile boxes and the medians suggests no significant difference. 20

Figure 5. Boxplots displaying differences in animal total counts in North Biscayne Bay (NBB) and Port of Miami (POM) in A, each sampling year throughout Fish and Invertebrate Assessment Network (FIAN) and Faunal Monitoring in Response to Harbor Dredging (FMHD), B, each year of the FMHD study (20142016) in each of the two study areas, and C, each basin by season (wet or dry) in all years of the FMHD study. The box represents the 25 to $75 \%$ interquartile range of values, the bold horizontal line inside the 
box represents the median value, the upper dashed line represents the maximum value of the third quartile plus 1.5 times the interquartile range, the lower dashed line is the minimum value of the first quartile minus 1.5 times the interquartile range, and circles are outliers. No overlap in the interquartile boxes indicates a significant difference, overlap in the interquartile boxes but not the medians indicates a likely significant difference, overlap in the interquartile boxes and the medians suggests no significant difference. 23

Figure 6. Bar graphs showing community structure changes from 2014 to 2016 in North Biscayne Bay (NBB) and Port of Miami (POM) for $A$, fish composition in NBB, $B$, fish composition in POM, $C$, shrimp composition in NBB, and $D$, shrimp composition in POM. Fishes and caridean shrimps were separated by genus. $\quad 25$

Figure 7. Kendall's tau correlation with $95 \%$ confidence intervals showing a negative correlation between $A$, turbidity (in nephelometric turbidity units [NTUs] and seagrass density; $B$, turbidity and combined totals of shrimps, fishes, and crabs; and $C$, a positive correlation between seagrass density and combined totals of shrimp, fishes, and crabs. 28

Figure 8. Nonmetric multidimensional scaling Euclidean distance graph created by using PRIMER 7. Graph visually depicts the resemblance of North Biscayne Bay (NBB) and Port of Miami (POM) community structures to each other through the years. 30

Figure 9. Average turbidities for North Biscayne Bay (NBB) and Port of Miami (POM) observed throughout the study period for the Faunal Monitoring in Response to Harbor Dredging (FMHD) and Fish and Invertebrate Assessment Network (FIAN) studies as a comparison of conditions before and after dredging. $\quad 33$

Figure 10. Average seagrass densities (as defined in table 1) for North Biscayne Bay (NBB) and Port of Miami (POM) observed throughout the study period for the Faunal Monitoring in Response to Harbor Dredging (FMHD) and Fish and Invertebrate Assessment Network (FIAN) studies as a comparison of conditions before and after dredging. 34 


\section{Tables}

Table 1. Braun-Blanquet categories of cover abundance rating used to quantify the seagrass community

present at each site sampled (Braun-Blanquet, 1965).

Table 2. Matrix showing mean, standard deviation (SD), and correlation between each of the factors of Faunal Monitoring in Response to Harbor Dredging (FMHD) data. Asterisks indicate correlations $\geq 0.15$ that were tested for statistical significance.... 16

Table 3. Permutational multivariate analysis of variance (PERMANOVA) test results of total numbers of caridean shrimp, penaeid shrimp, and fish by location, year, season, and interactions between factors for Faunal Monitoring in Response to Harbor Dredging (FMHD) data. Sources of variation in models, $\mathrm{df}=$ degrees of freedom, SS=sums of squares, MS=mean squares, Pseudo-F statistic, and $P($ perm $)=$ attained significance level. Results were considered significant at $P($ perm $)<0.05)$. 


\section{Conversion Factors}

U.S. customary units to International System of Units

\begin{tabular}{lcll}
\hline & Bultiply & & To obtain \\
\hline & Length & & \\
\hline foot $(\mathrm{ft})$ & 0.3048 & meter $(\mathrm{m})$ &
\end{tabular}

\section{Conversion Factors}

International System of Units to U.S. customary units

\begin{tabular}{lcll}
\hline & Bultiply & & To obtain \\
\hline & Length & & \\
\hline millimeter $(\mathrm{mm})$ & 0.03937 & inch (in.) & \\
meter $(\mathrm{m})$ & 3.281 & foot (ft) & \\
meter $(\mathrm{m})$ & 1.094 & yard (yd) & \\
\hline & Area & & \\
\hline square meter $\left(\mathrm{m}^{2}\right)$ & 0.0002471 & acre
\end{tabular}




\title{
Faunal and Vegetation Monitoring in Response to Harbor Dredging in the Port of Miami
}

\author{
By Andre Daniels, Rachael Stevenson², Erin Smith², and Michael Robblee ${ }^{3}$
}

${ }^{1}$ U.S. Geological Survey Wetland and Aquatic Research Center; ${ }^{2}$ Nova Southeastern University, Dania Beach, Florida; ${ }^{3}$ U.S. Geological Survey Wetland and Aquatic Research Center, emeritus

\begin{abstract}
Seagrasses are highly productive ecosystems. A before-after-control-impact (BACI) design was used to examine effects of dredging on seagrasses and the animals that inhabit them. The control site North Biscayne Bay and the affected site Port of Miami had seagrass densities decrease during both the before, Fish and Invertebrate Assessment Network 2006-2011, and after, Faunal Monitoring in Response to Harbor Dredging 2014-2016, studies. Turbidity levels increased at North Biscayne Bay and Port of Miami basins during the Faunal Monitoring in Response to Harbor Dredging study, especially in 2016. Animal populations decreased significantly in North Biscayne Bay and Port of Miami in the Faunal Monitoring in Response to Harbor Dredging study compared to the Fish and Invertebrate Assessment Network study. Predictive modeling shows that numbers of animal populations will likely continue to decrease if the negative trends in seagrass densities continue unabated. There could be effects on several fisheries vital to the south Florida economy. Additional research could determine if animal populations and seagrass densities have rebounded or continued to decrease.
\end{abstract}

\section{Introduction}

Seagrass communities are among the most productive and ecologically important global ecosystems. They provide high primary production that supports diverse food webs, maintain water quality by filtering contaminants and binding sediments to reduce turbidity, and serve as a resource for various marine species. Resources provided include protective cover, food, and nursery habitat. However, seagrass beds are extremely sensitive to anthropogenic effects and therefore have been placed among the most endangered ecosystems in the world (d'Avack and others, 2014, Schlacher-Hoenlinger and Schlacher, 1998). One of the most detrimental human activities that damages seagrass beds is dredging and accompanying turbidity. Dredging to accommodate commercial ships causes physical damage to seagrass beds and lasting ecological effects by disturbing seagrass sediments (Erftmeijer and Lewis, 2006). The present study focused on the effects of the Deep Dredge project at the Port of Miami, which was implemented in 2014-2015 to allow larger ships to access and utilize the port.

This study is a continuation of the Faunal Monitoring in Response to Harbor Dredging (FMHD) project. Faunal Monitoring in Response to Harbor Dredging monitors and assesses faunal abundance and composition with associated vegetation in North Biscayne Bay (NBB) and the Port of Miami (POM). The FMHD project is designed to track possible effects of dredging on seagrass habitats adjacent to the port. To allow for comparison of results, the experimental design and methods from the South Florida Fish and Invertebrate Assessment Network (FIAN) 
were used, which was part of the Restoration, Coordination, and Verification (RECOVER, 2004) program of the Comprehensive Everglades Restoration Plan (CERP) (Robblee and Browder, written communication to USACE, USGS, and NOAA National Marine Fisheries Service). Samples were collected from both locations over 3 years, 2014-2016, to assess the status of the seagrass ecosystems before, during, and after completion of the dredging project. FIAN samples were collected in NBB and POM from 2005 to 2011. These data were used as a baseline to compare results from the FMHD.

\section{Background}

\section{Seagrasses}

Seagrasses are flowering vascular plants that are widespread in estuarine and marine environments around the world. Seagrass communities are one of the most productive coastal marine ecosystems and a major benthic feature of the shallow coastal waters of southern Florida (Short and others, 2007). Seagrass beds serve as food, habitat, and nursery grounds for a host of marine organisms. For example, sea turtles and manatees rely heavily on seagrass for food (Serafy and others, 1997). Seagrasses also provide habitat for diverse vertebrate and invertebrate communities and support economically important fisheries, such as the Caribbean spiny lobster, stone crab, and pink shrimp.

Seven species of seagrass can be found in southern Florida, the majority of coverage consists of Thalassia testudinum (turtle grass), Halodule wrightii (shoal grass), and Syringodium filiforme (manatee grass). Turtle grass is the dominant species in distribution and biomass and is an important component of the diet of the green sea turtle (Chelonia mydas) (Fuentes and others, 2006). Shoal grass tends to be locally dominant in recently disturbed areas, and often becomes established rapidly after-disturbance. This species is typically found in areas with extreme temperatures and salinities or in low light conditions. Manatee grass is generally prominent in deeper marine waters compared to shallower shoal and turtle grass beds (Fourqurean and others, 2001).

\section{Dredging}

Dredging is necessary in large ports around the world to maintain and deepen channels to allow access for large cargo ships (Erftemeijer and others, 2006). The Port of Miami is an economically important seaport that supports about 225,000 jobs and contributes approximately $\$ 30$ billion to the local economy. The Deep Dredge Project in the Port of Miami was designed to widen and deepen the channel to 50 feet to allow super post-Panamax megaships to utilize the port. This project was completed in September 2015 (U.S. Army Corps of Engineers, n.d.).

The dredging process causes large-scale disturbance in the surrounding area and can lead to many negative effects on the ecosystem including decreases in water quality with increased turbidity and sedimentation, hydrographic changes, and shifts in the community structure of plants and organisms (Lohrer and Wetz, 2003; Behringer and Butler, 2006). One of the most significant dredging related issues for seagrasses is mechanical destruction, including physical removal or burial of the grasses. For the organisms that inhabit seagrass beds, there can be decreases in primary production, loss of inhabitable space, decreases in the nutritional quality of food, and reduced feeding success of visual predators and filter feeders (Essink, 1999). The 
increased silt layer on the seafloor can also lead to anoxic bottom conditions and smothering of corals, sponges, and grasses.

\section{Faunal Monitoring in Response to Harbor Dredging}

The FMHD project was designed by using the FIAN methodology to evaluate the effects of dredging in the Port of Miami over 3 years (2014-2016). The purpose of FIAN was to monitor seagrass fauna, including fish, crabs, and caridean and penaeid shrimp, in relation to benthic vegetation, substrate, and environmental conditions, turbidity in particular. Samples were collected at the end of the dry and wet seasons, April and September respectively. The 7-year FIAN project (from 2005 to 2011) provided a baseline prior to dredging the port (Robblee and Browder, written communication to USACE, USGS, and NOAA National Marine Fisheries Service). FMHD was carried out by the U. S. Geological Survey (USGS) using laboratory facilities from Nova Southeastern University's Oceanographic Center in Dania Beach, Florida.

\section{Methods}

\section{Sampling Locations}

This project compared seagrass communities in two basins, NBB and the POM (fig. 1). Sampling sites in NBB are between Miami and the Miami Beach barrier island from John F. Kennedy Causeway to Julia Tuttle Causeway. The POM sampling sites are located south of the port down to Rickenbacker Causeway.

\section{Experimental Design}

The sampling design of the FMHD was the same as that of FIAN which utilized a sampling grid of 30, equal-sized hexagonal cells. Thirty sites were used for statistical analysis. Two FIAN sampling locations, POM and NBB, were selected. The POM sites were located adjacent to the area to be dredged, whereas the NBB would serve as a "control" to identify regional patterns. The premise was if similar changes occurred at both sites, dredging may not account for the observed changes, whereas changes only observed in POM may be attributable to dredging activities. Sample sites were visited biannually at the end of the dry and wet seasons in the first 2 weeks of April and September, respectively. Fig. 1 shows the 30 cells sampled in each of the two locations. Within each cell, up to five random locations were visited and inspected for the presence of benthic vegetation, including seagrasses and algae. Once a location with benthic vegetation was found, that station was sampled and no alternate locations were visited. If vegetation was absent, the remaining alternates were visited until vegetation was present. If each of the alternates was found devoid of vegetation, the fifth site was sampled and categorized as unvegetated. 

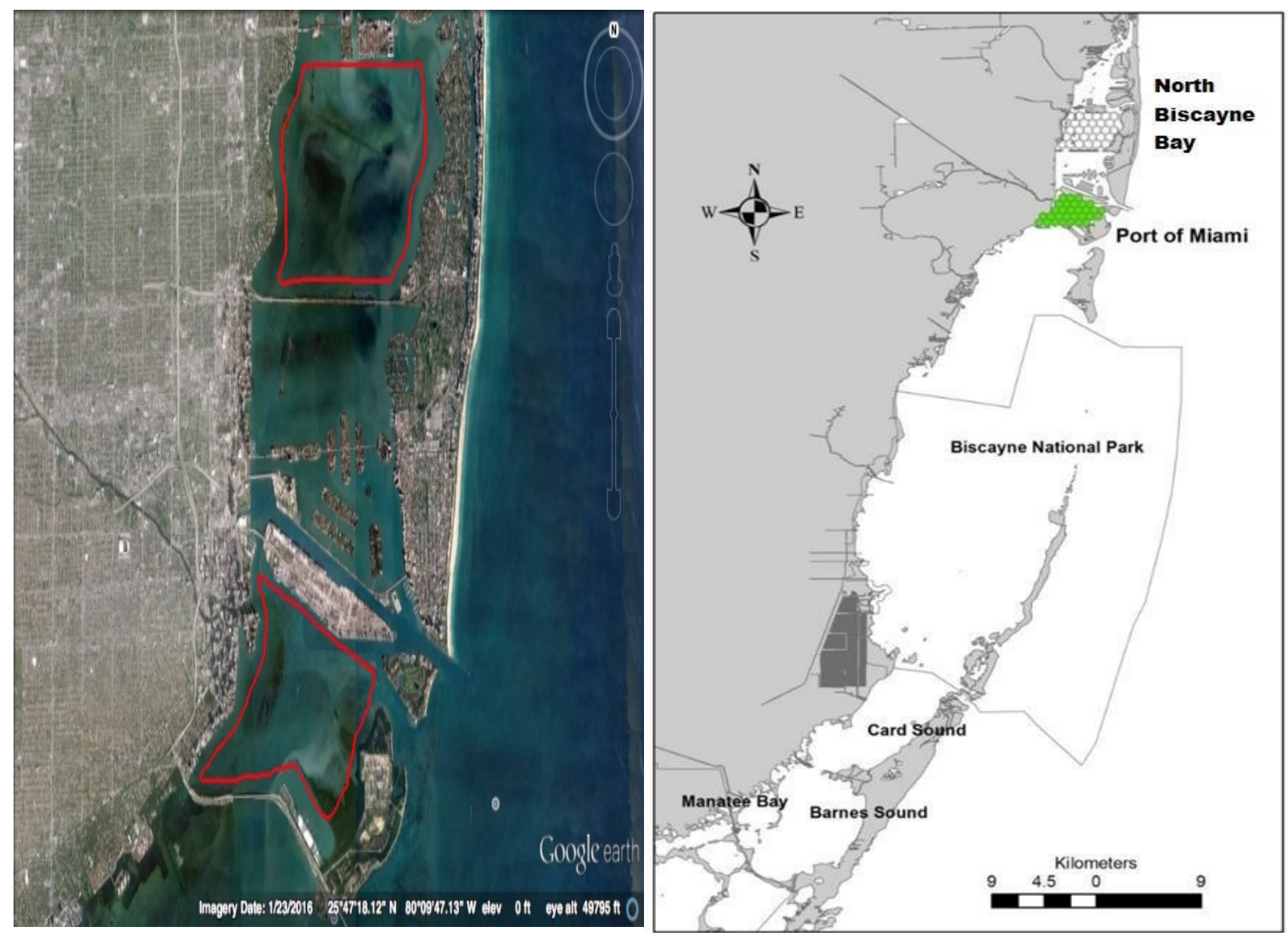

Figure 1. Google Earth image of study areas (left) with both basins outlined in red. The top area is North Biscayne Bay (NBB) and the bottom area is Port of Miami (POM). A map of Biscayne Bay (right) showing the 30 cells in each of the two sampling grids for North Biscayne Bay (white) and Port of Miami (green).

\section{Physical and Environmental Field Measurements}

Once a sampling location was chosen, coordinates were recorded by using a Garmin GPSMAP492 Global Positioning System unit (World Geodetic System 1984 datum). Physical and environmental field measurements were taken at each of the 30 sample sites. Salinity and temperature were measured within 1 meter $(\mathrm{m})$ of the surface and within $1 \mathrm{~m}$ of the bottom substrate surface at each site by using a hand-held WTW 330i Conductivity Field Meter (or equivalent, 315i). Turbidity measurements were made by collecting a single grab sample in undisturbed water just below the surface at the collection site. The sample was placed on ice on the boat, and stored in a refrigerator until analysis at the lab. An HF Scientific DRT-15CE portable turbidity meter over three selectable ranges, (0-10, $0-100$, and $0-1,000$ nephelometric turbidity units (NTUs), was used to measure turbidity. 


\section{Braun-Blanquet Method}

The project utilized a modified Braun-Blanquet technique to quantify vegetation cover and abundance (Braun-Blanquet, 1965). The Braun-Blanquet technique involves visually quantifying the cover and abundance of seagrass and algae observed in a 0.25 -square meter $\left(\mathrm{m}^{2}\right)$ quadrat. In total, six replicates were collected at each sample point, with five being distributed in a semicircle around the boat and throw-trap and the sixth being immediately next to the throwtrap (fig. 2). Substrate type was recorded along with species of vegetation present. Bottom substrate was categorized as mud, sandy mud, muddy sand, sand, coarse shell, rubble, Halimeda (algae) hash, or a combination of these types. Seagrasses observed were Thalassia testudinum, Halodule wrightii, Syringodium filiforme, and various Halophila species (for example, $H$. engelmanni, $H$. decipiens, H.johnsonii). The canopy height (general height of each taxon) was measured for each species of seagrass present, or the height of the algae measured if no seagrass was present. Each taxon was then assigned a density score (table 1). The upper end of the scale is generally for seagrasses and upright algae that cover more than 75 percent of the given quadrat. Littler and others (1989) and Green and Short (2003) were used to identify and characterize algae and seagrass, respectively.

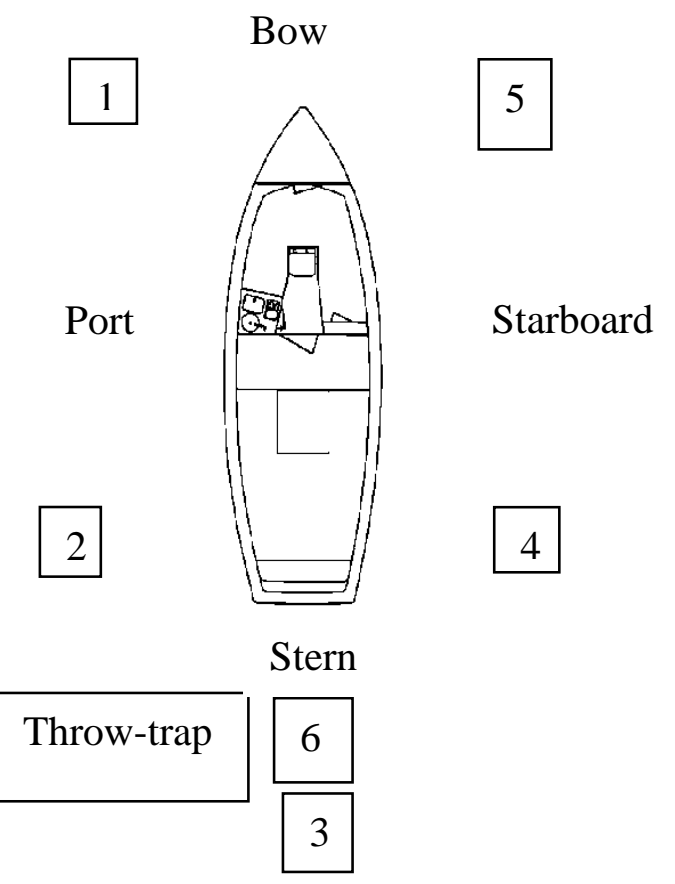

Figure 2. Location of Braun-Blanquet replicate habitat samples in relation to the anchored boat and throw-trap. 
Table 1. Braun-Blanquet categories of cover abundance rating used to quantify the seagrass community present at each site sampled (Braun-Blanquet, 1965).

\begin{tabular}{r|l} 
Density & Description \\
0 & Absent or no measurable cover \\
0.1 & Solitary shoot with small cover \\
0.5 & Few shoots, less than $5 \%$ cover \\
1 & Numerous shoots, less than $5 \%$ cover \\
2 & Any number of shoots but with $5 \%$ to $25 \%$ cover \\
3 & Any number of shoots but with $25 \%$ to $50 \%$ cover \\
4 & Any number of shoots but with $50 \%$ to $75 \%$ cover \\
5 & Any number of shoots but with $>75 \%$ cover
\end{tabular}

\section{Animal Collection Method}

To quantitatively sample the epibenthos, a $1-\mathrm{m}^{2}$ throw-trap was used at each of the 30 cells in the sampling grid. The throw-trap was thrown into undisturbed water behind the boat and immediately covered with panels of weighted nylon netting (0.16-mm DELTA stretched mesh) attached on parallel edges at the top of the trap. When the trap was in place, fish and invertebrates were collected with five separate passes of a sweep net. Sweep nets were dragged across the bottom inside the throw-trap while cover netting was pushed forward simultaneously to prevent the escape of animals. In water depths greater than $0.75 \mathrm{~m}$, surface-supplied hookah equipment was used. The five sweep nets were returned to the boat and rinsed over a 1millimeter (mm) sieve and placed in similar sized mesh netting bags. The samples were stored in an ice bath until they could be fixed in a 10 percent Formalin solution or frozen until the samples were sorted. The organisms were identified to the lowest possible taxonomic level and stored in 70 percent Ethanol.

\section{Statistical Analysis}

Statistical analyses included both parametric and nonparametric tests with a significance level of $p<0.05$. Data were tested for normality and homogeneity of variances to determine appropriate statistical test. Simple analysis of variance (ANOVA) was used to evaluate the relationships among study sites and years, environmental factors, and fauna/flora. These relationships included differences in turbidity, seagrass density, and faunal composition by years, locations, and seasons. Post-hoc multiple comparison tests were used on statistically significant models to determine which factors could be attributed to observed changes. Results were also compared with FIAN data as a baseline. Permutational multivariate analysis of variance (PERMANOVA) was used as the before-after-control-impact (BACI) test for differences in total numbers of caridean shrimp, penaeid shrimp, and fish by location, year, season, and interactions between factors (Smith and others, 1993; Smith, 2002). The biostatistics package Quest Research Limited PRIMER 7 was used to generate nonmetric multidimensional scaling plots to compare 
the community similarities before, during, and after dredging in POM and NBB. Data were normalized prior to generating a resemblance matrix based on Euclidean distance.

\section{Results}

Variables measured in this study included salinity, turbidity, temperature, seagrass density, and total counts of animals. A correlation matrix was used to show relationships between these factors (table 2). All correlations of 0.15 or higher were tested for significance, along with all temperature and salinity measurements. The significant negative correlation between salinity and temperature was expected because high salinity ocean waters are cooler. These two variables were not considered to be impacted by the dredging. The variables that were significantly altered during the project were turbidity, seagrass density, and total counts of animals. There was also a shift in faunal composition in caridean and penaeid shrimp and fish in NBB and POM over the course of the 3-year monitoring periods.

Table 2. Matrix showing mean, standard deviation (SD), and correlation between each of the factors of Faunal Monitoring in Response to Harbor Dredging (FMHD) data. Asterisks indicate correlations $\geq 0.15$ that were tested for statistical significance.

\begin{tabular}{r|llllllll}
\multicolumn{2}{l}{ Factor } & Mean & SD & 1 & 2 & 3 & 4 & 5 \\
\hline 1 & Salinity & 32.57 & 3.50 & - & & & & \\
2 & Turbidity & 2.97 & 2.29 & -0.10 & - & & \\
3 & Temperature & 28.30 & 2.62 & $-0.40^{*}$ & -0.13 & - & & \\
4 & Seagrass & 1.28 & 1.07 & 0.13 & $-0.21^{*}$ & 0.05 & - & \\
& density & & & & & & & \\
5 & Animal totals & 28.53 & 44.75 & 0.11 & $-0.15^{*}$ & 0.08 & $0.41^{*}$ & -
\end{tabular}

\section{Turbidity}

During the FIAN and FMHD studies, turbidity (as NTU) was gradually decreasing overall until 2016, when values noticeably increased (fig. 3A). For both sites combined, one-way ANOVA showed a significant increase in surface water turbidity over the three years of FMHD $(p<0.001)$, though there was no significant difference in turbidity by season or between both locations. Both locations showed significant differences in turbidity by year. Significant increases in turbidity ( $p<0.001)$ were observed in both NBB and POM over the 3 years (fig. 3B). There were significant differences in turbidity at NBB between 2014 and 2016 and between 2015 and $2016(p<0.001)$, but not between 2014 and 2015. Similar differences were observed at POM where significant differences were observed among 2014 to 2016 and between 2015 and 2015 $(p<0.001)$ but not between 2014 and 2015. There was no significant difference in turbidity between seasons at the two locations (fig. 3C). 

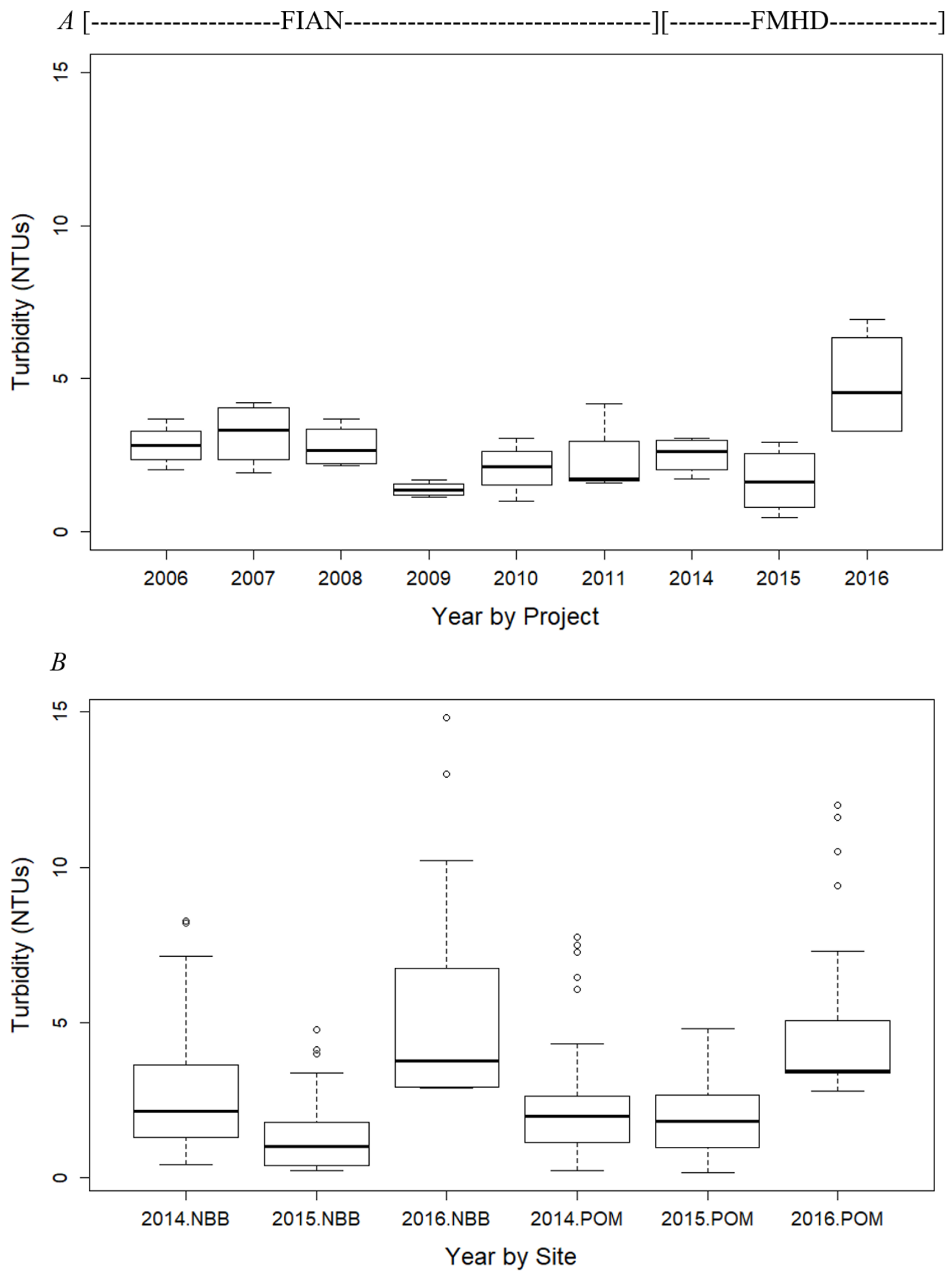


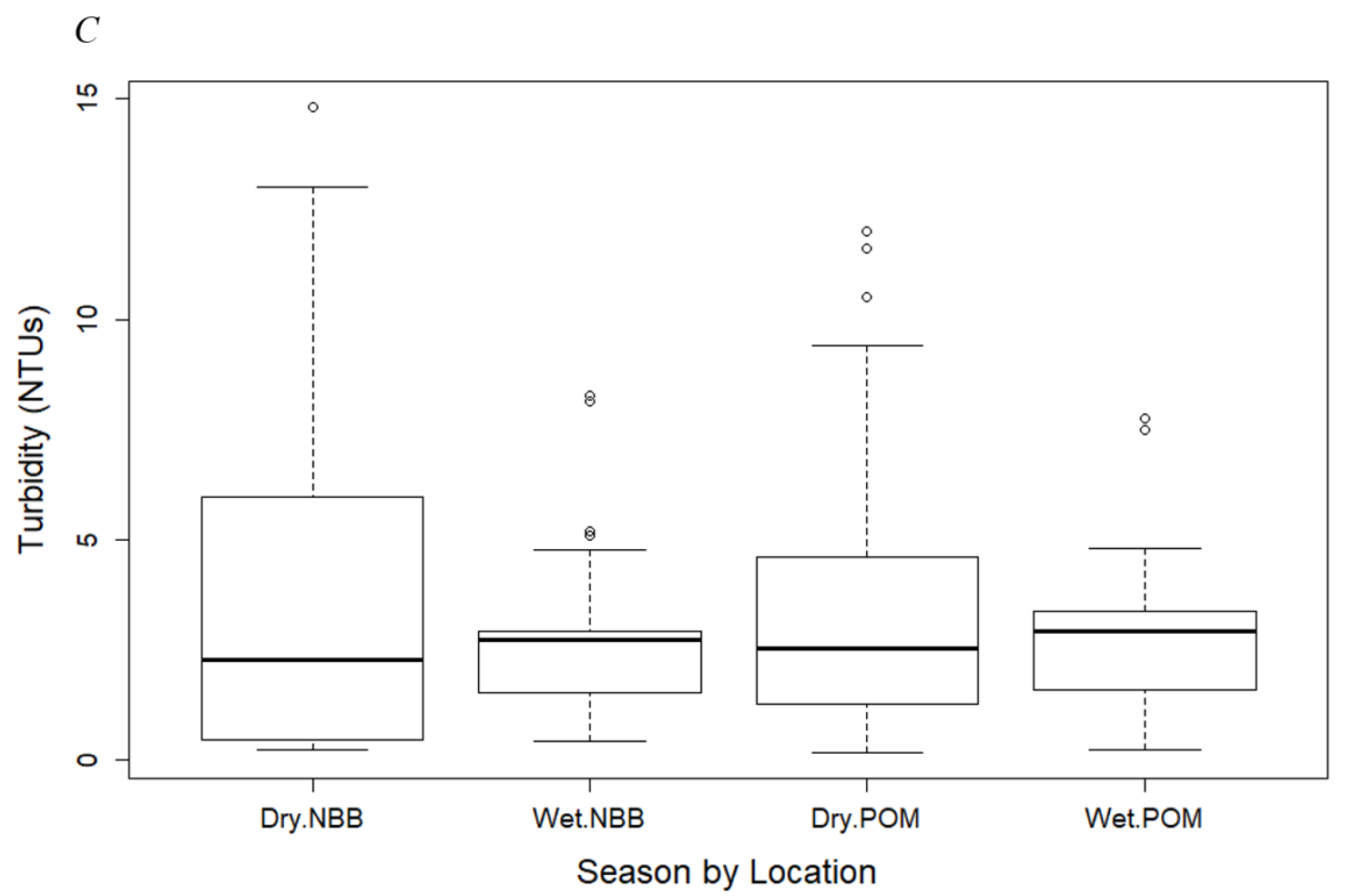

Figure 3. Boxplots displaying turbidity values (in nephelometric turbidity units [NTUs]) in North Biscayne Bay (NBB) and Port of Miami (POM) in A, each sampling year throughout Fish and Invertebrate Assessment Network (FIAN) and Faunal Monitoring in Response to Harbor Dredging (FMHD), $B$, each year of the FMHD study (2014-2016) in each of the two study areas, and C, each basin by season (wet or dry) in all years of the FMHD study. The box represents the 25 to $75 \%$ interquartile range of values, the bold horizontal line inside the box represents the median value, the upper dashed line represents the maximum value of the third quartile plus 1.5 times the interquartile range, the lower dashed line is the minimum value of the first quartile minus 1.5 times the interquartile range, and circles are outliers. No overlap in the interquartile boxes indicates a significant difference, overlap in the interquartile boxes but not the medians indicates a likely significant difference, overlap in the interquartile boxes and the medians suggests no significant difference.

\section{Seagrass Density}

Overall, seagrass density showed a significant decrease through time from the FIAN study to the FMHD study ( $p<0.001$; fig. $4 A$ ). With both sites combined for FMHD, there was a significant change in seagrass density among years $(p<0.001)$. At both locations, significant decreases in seagrass density were observed beginning in 2015 and into 2016 (fig. 4B). Seagrass density in NBB had a significant decrease by year $(p<0.05)$. There was a significant difference between 2014 and $2016(p<0.001)$ and between 2015 and $2016(p<0.05)$, but no significant 
difference between 2014 and 2015. POM showed similar significant decreases by year $(p<0.001)$. There was a significant difference between 2014 and $2016(p<0.001)$ and between 2015 and $2016(p<0.001)$. Similar to NBB, there was no significant difference in seagrass density between years 2014 and 2015 (fig. 4), suggesting dredging had not yet had a measurable impact. There were no significant differences in seagrass density between seasons at either location (fig. 4C).

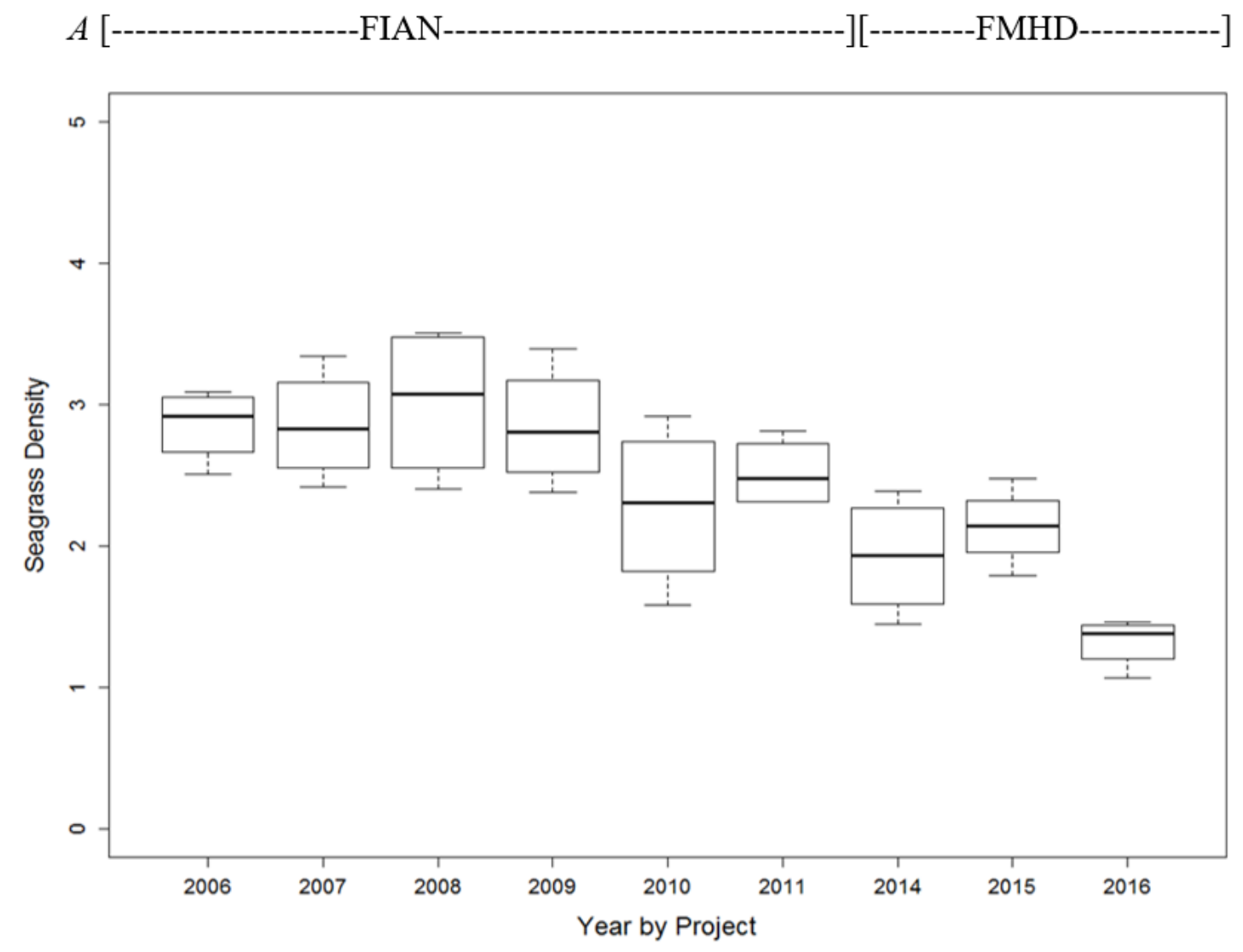



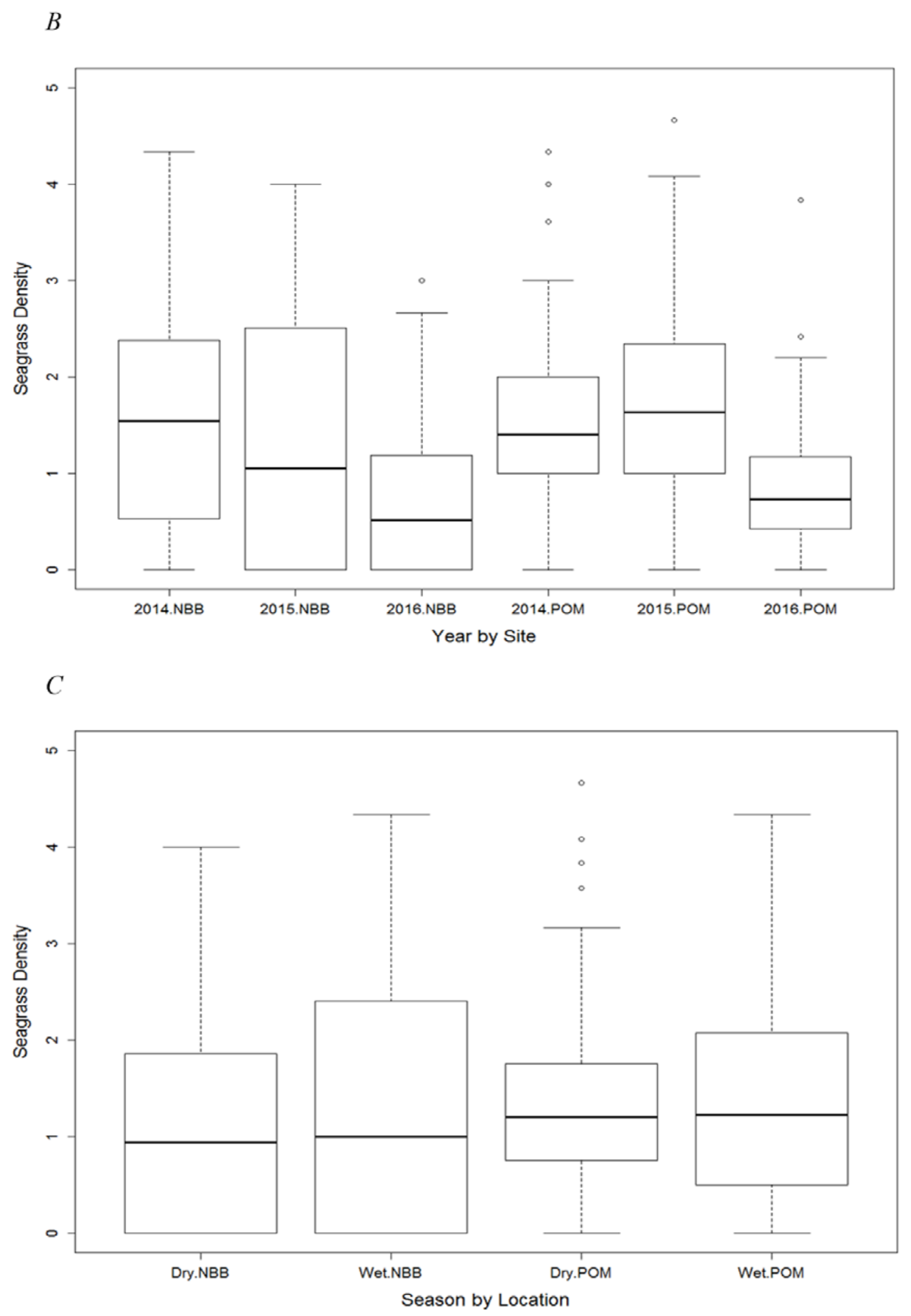

Figure 4. Boxplots displaying differences in average seagrass densities using the Braun-Blanquet (1965) scale in North Biscayne Bay (NBB) and Port of Miami (POM) in A, each sampling year throughout Fish and 
Invertebrate Assessment Network (FIAN) and Faunal Monitoring in Response to Harbor Dredging (FMHD), $B$, each year of the FMHD study (2014-2016) in each of the two study areas, and C, each basin by season (wet or dry) in all years of the FMHD study. The box represents the 25 to 75 percent interquartile range of values, the bold horizontal line inside the box represents the median value, the upper dashed line represents the maximum value of the third quartile plus 1.5 times the interquartile range, the lower dashed line is the minimum value of the first quartile minus 1.5 times the interquartile range, and circles are outliers. No overlap in the interquartile boxes indicates a significant difference, overlap in the interquartile boxes but not the medians indicates a likely significant difference, overlap in the interquartile boxes and the medians suggests no significant difference.

\section{Animal Totals}

There were significant differences in animal totals by year $(p<0.05)$ and site $(p<0.001)$, but no significant differences between seasons (fig. 5A-C). Overall, NBB showed slight although significant decreases in caridean shrimps (Alpheus, Hippolyte, Thor, Latreutes, Paleaemonetes., Periclimenes, and Processa), penaeid shrimps (Farfantepenaeus), and fishes (Floridichthys, Lucania, Ctenogobius, Gobiosoma, Microgobius, and Hippocampus) ( $p<0.05$ for all) throughout the study period. Sites at POM also showed a similar significant decrease in carideans $(\mathrm{p}<0.05)$, penaeids $(p<0.05)$, and fishes $(p<0.001)$ throughout the study period (Figure $5 B)$. There were significantly more animals at the POM than at the NBB for all 3 years $(p<0.001)$. Caridean shrimp, penaeid shrimp, and fish totals all showed significant changes throughout the FMHD in both locations. There were also considerable shifts observed in the community assemblages of fish and shrimp in both locations (fig. 6A-D). 

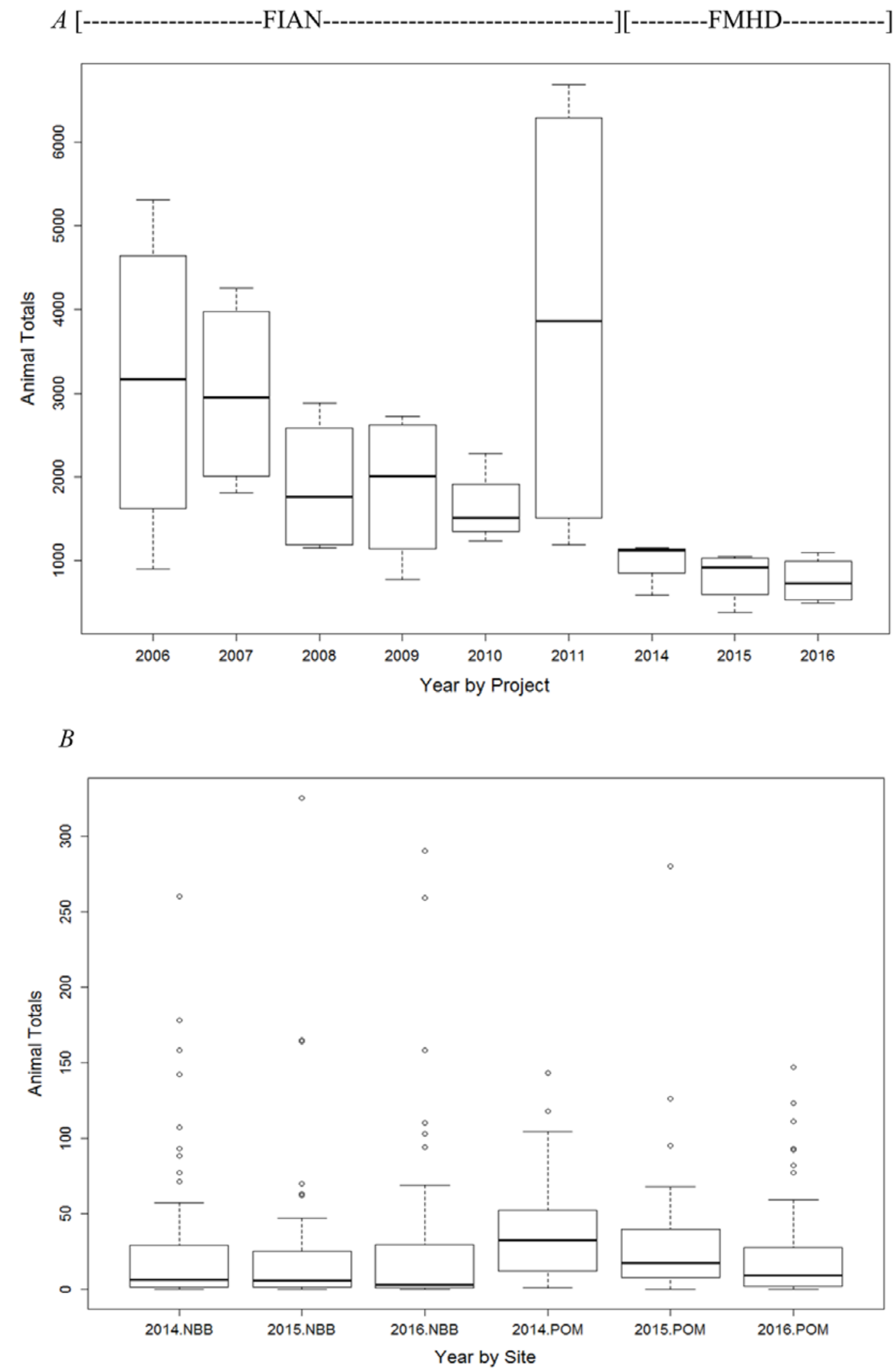


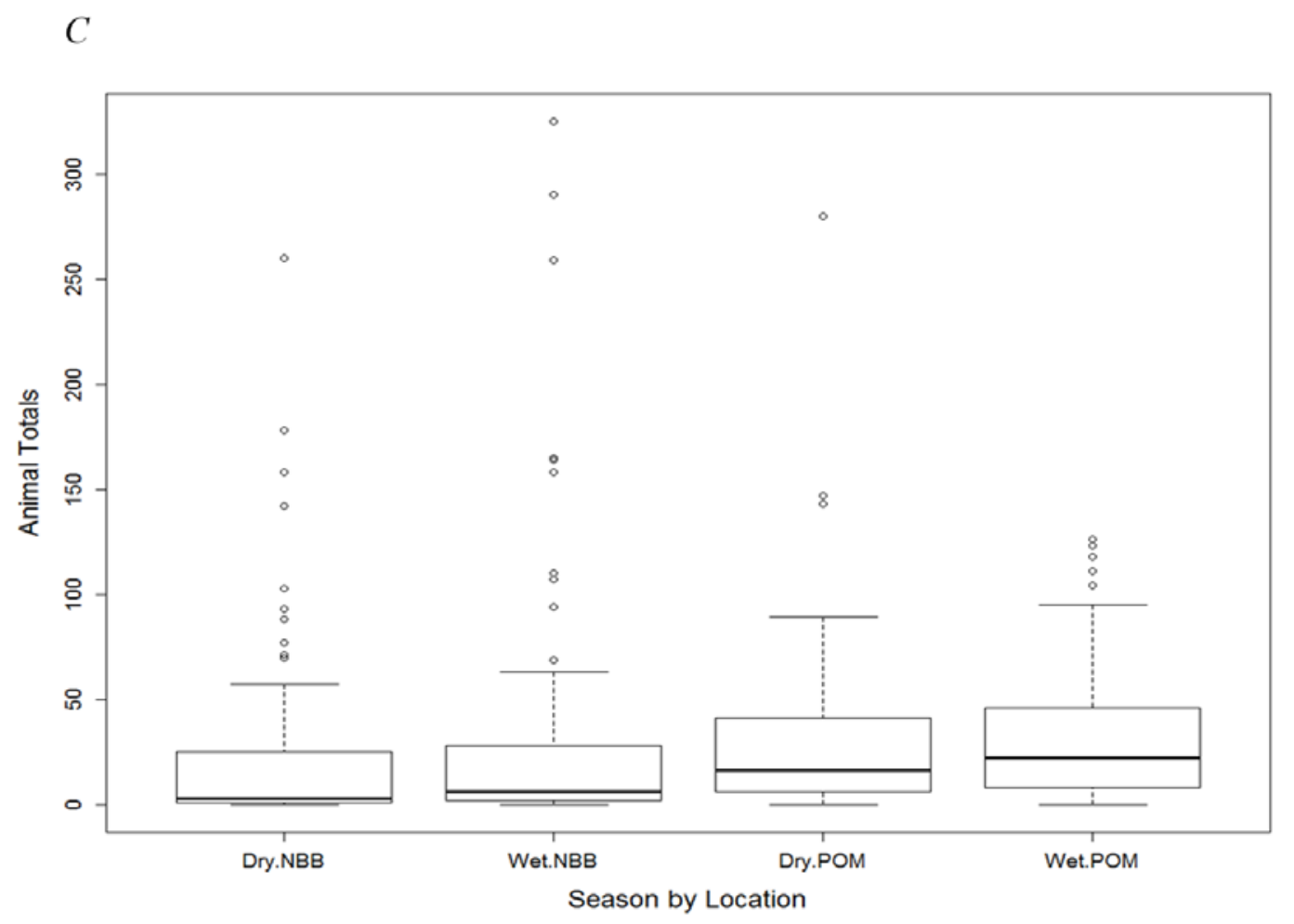

Figure 5. Boxplots displaying differences in animal total counts in North Biscayne Bay (NBB) and Port of Miami (POM) in A, each sampling year throughout Fish and Invertebrate Assessment Network (FIAN) and Faunal Monitoring in Response to Harbor Dredging (FMHD), B, each year of the FMHD study (2014-2016) in each of the two study areas, and $C$, each basin by season (wet or dry) in all years of the FMHD study. The box represents the 25 to $75 \%$ interquartile range of values, the bold horizontal line inside the box represents the median value, the upper dashed line represents the maximum value of the third quartile plus 1.5 times the interquartile range, the lower dashed line is the minimum value of the first quartile minus 1.5 times the interquartile range, and circles are outliers. No overlap in the interquartile boxes indicates a significant difference, overlap in the interquartile boxes but not the medians indicates a likely significant difference, overlap in the interquartile boxes and the medians suggests no significant difference. 
A)

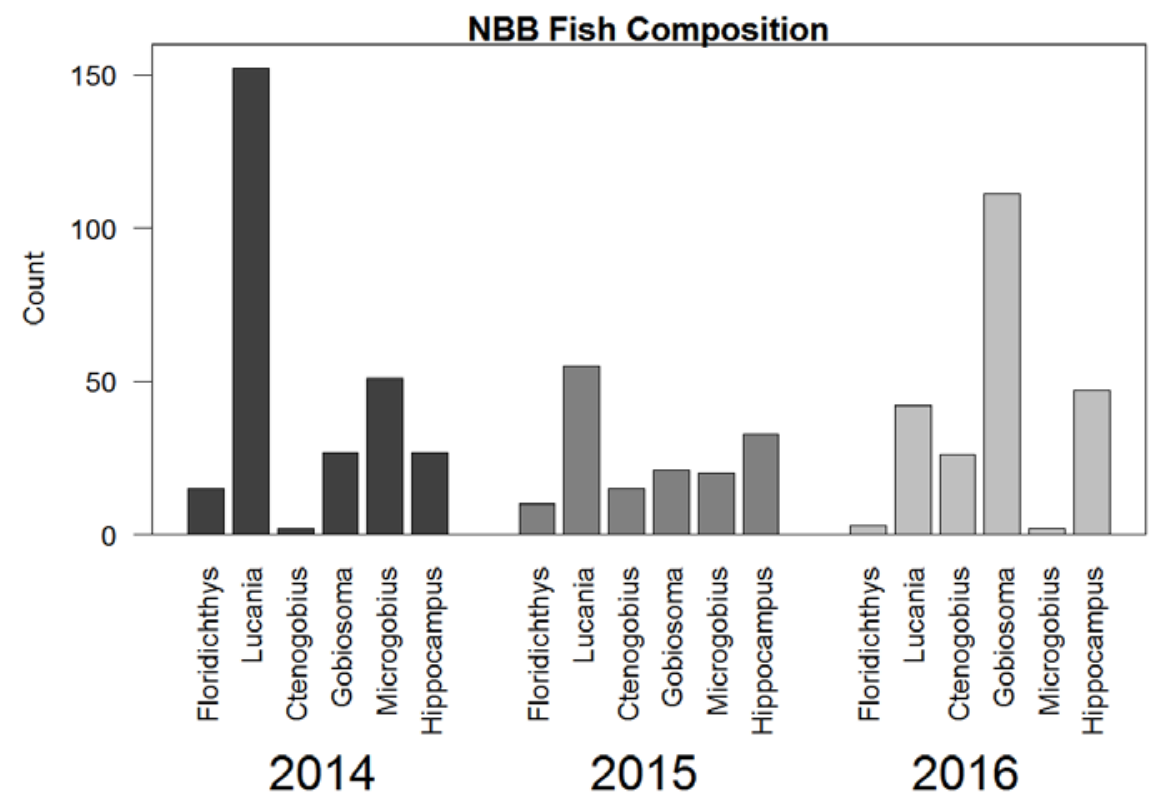

B)

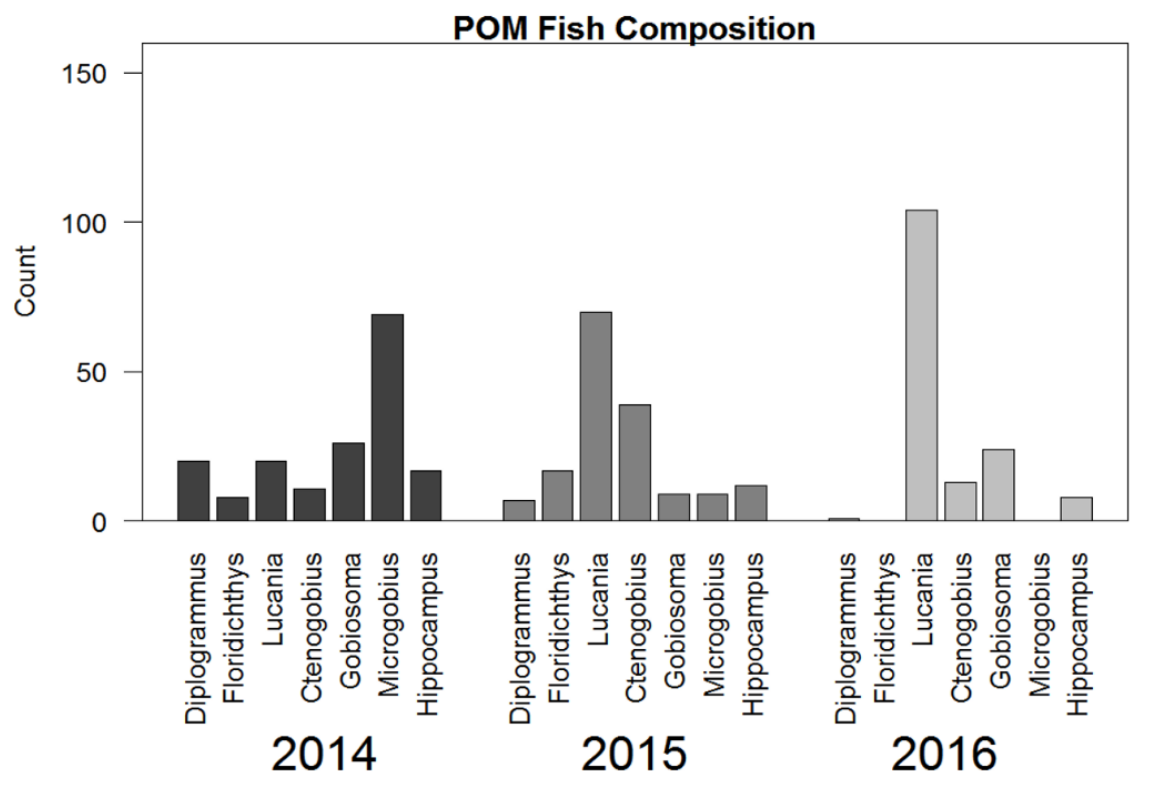


C)

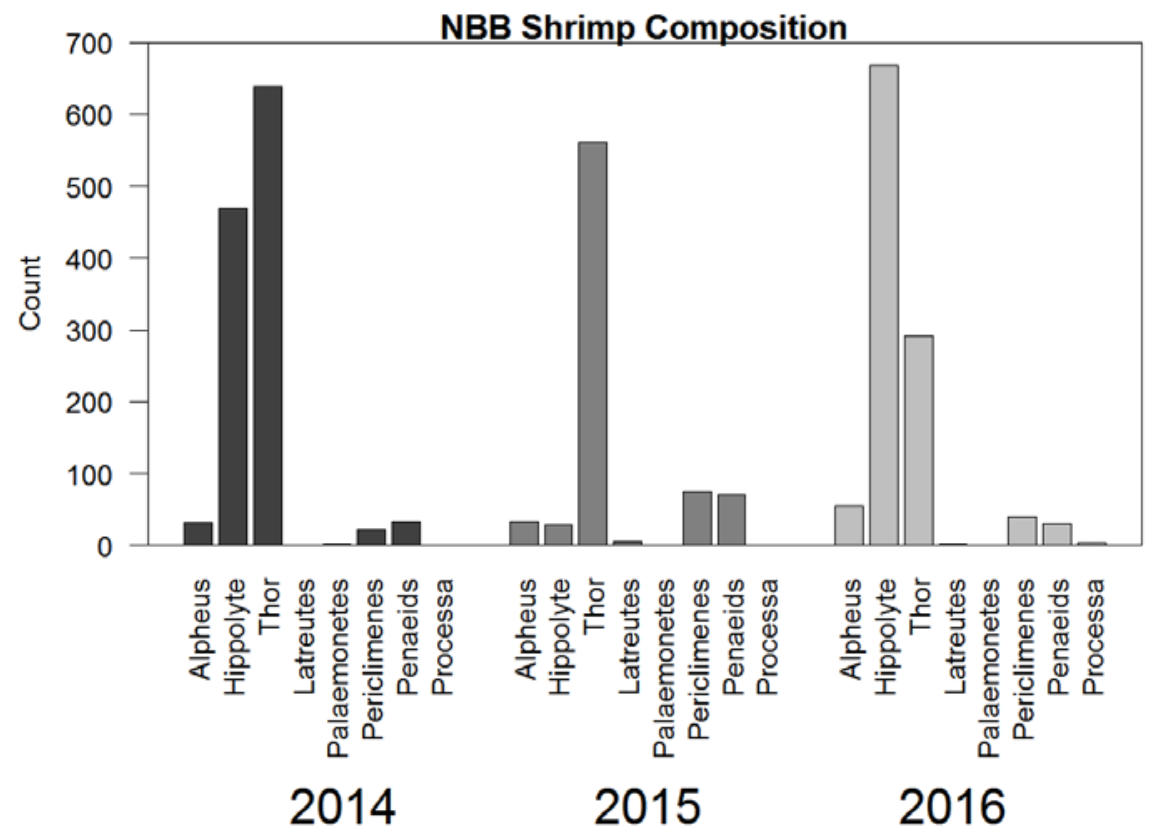

D)

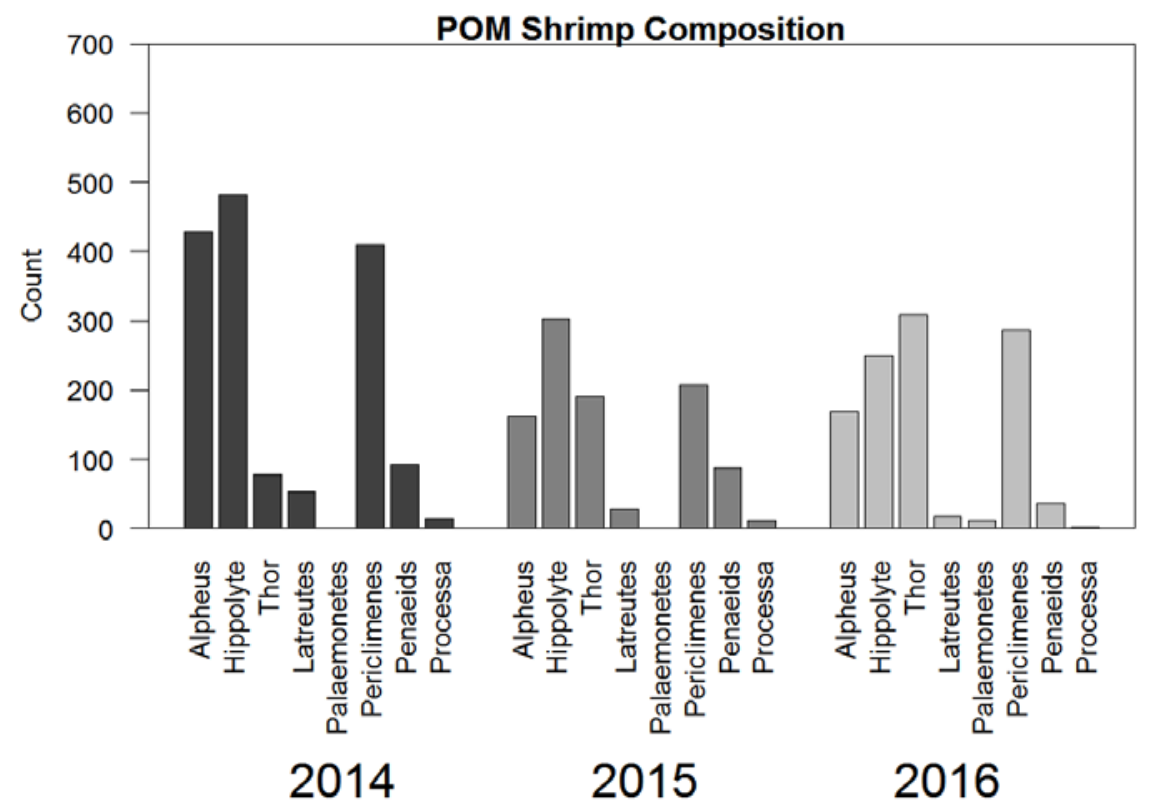

Figure 6. Bar graphs showing community structure changes from 2014 to 2016 in North Biscayne Bay (NBB) and Port of Miami (POM) for $A$, fish composition in NBB, $B$, fish composition in POM, $C$, shrimp composition in NBB, and $D$, shrimp composition in POM. Fishes and caridean shrimps were separated by genus. 


\section{Turbidity, Seagrass Density, and Animal Totals}

Kendall's tau correlation tests were used to examine relationships between turbidity and seagrass density, turbidity and animal totals, and seagrass density and animal totals. The test showed that seagrass density was negatively correlated with turbidity $(p<0.001, \tau=-0.2076391$; fig. $7 A)$. Total animal abundance for the four groups combined, was also negatively correlated to turbidity $(p<0.001, \tau=-0.1471443$; fig. $7 B$ ). Seagrass density was positively correlated to animal totals $(p<0.001, \tau=0.4107495$; fig. $7 C)$. 


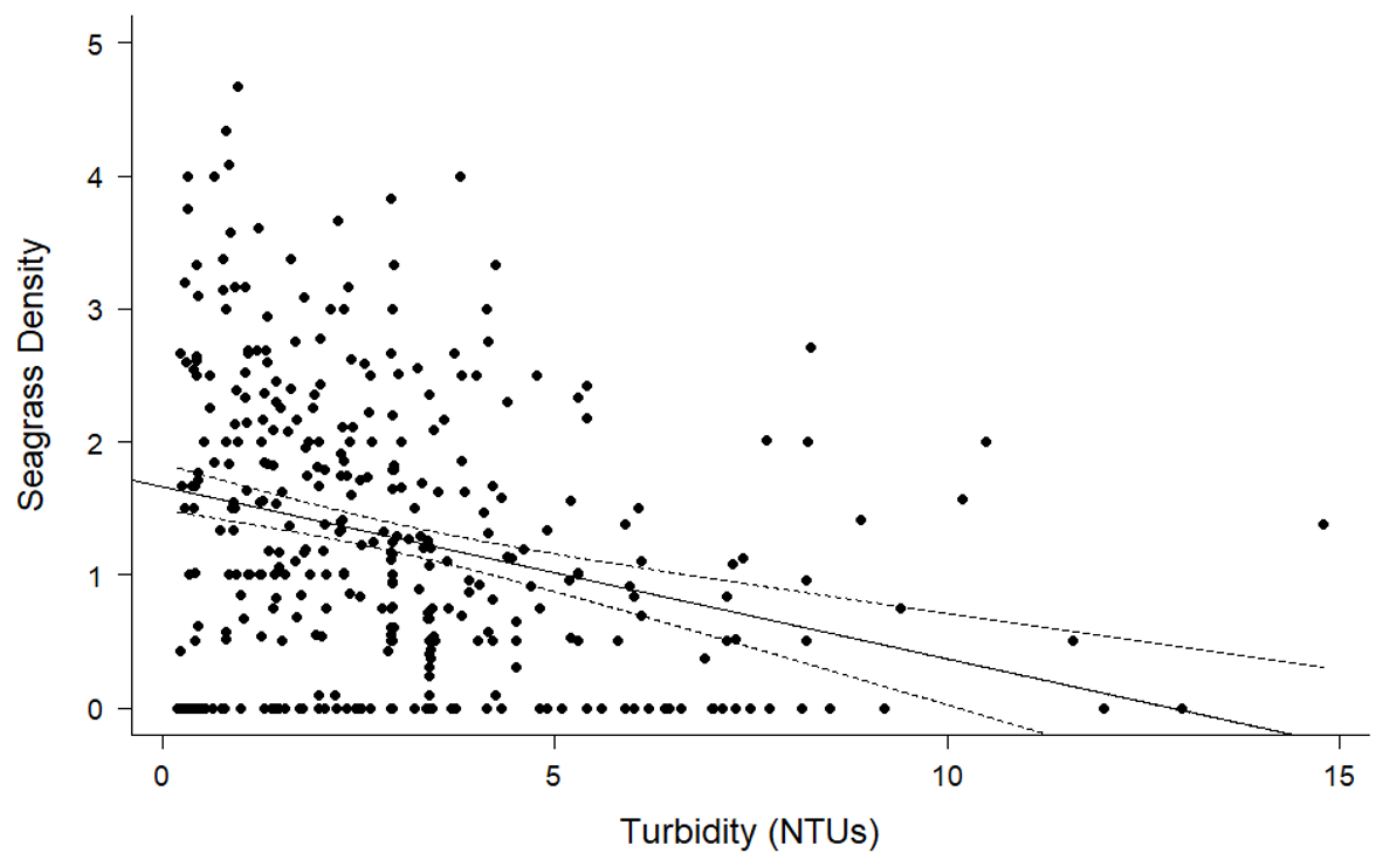

B

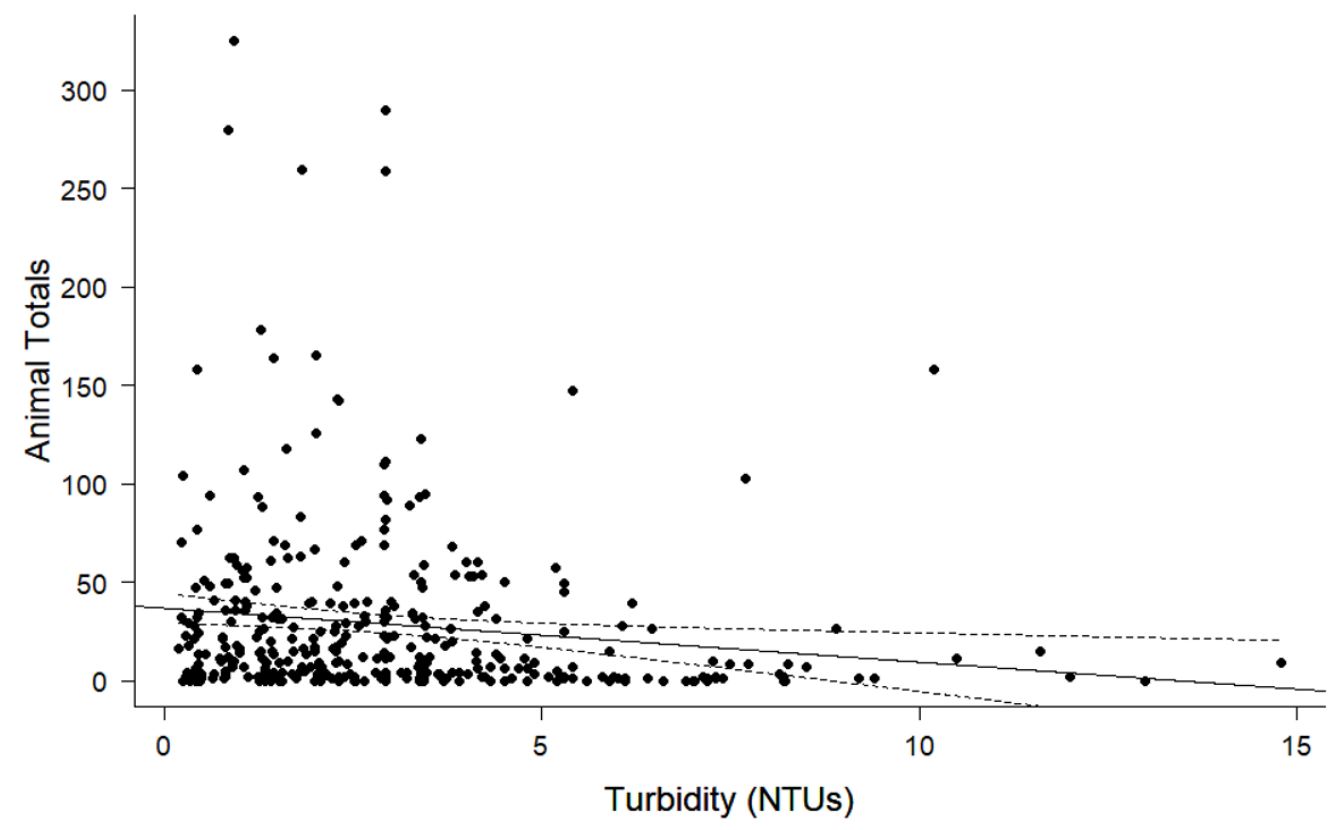




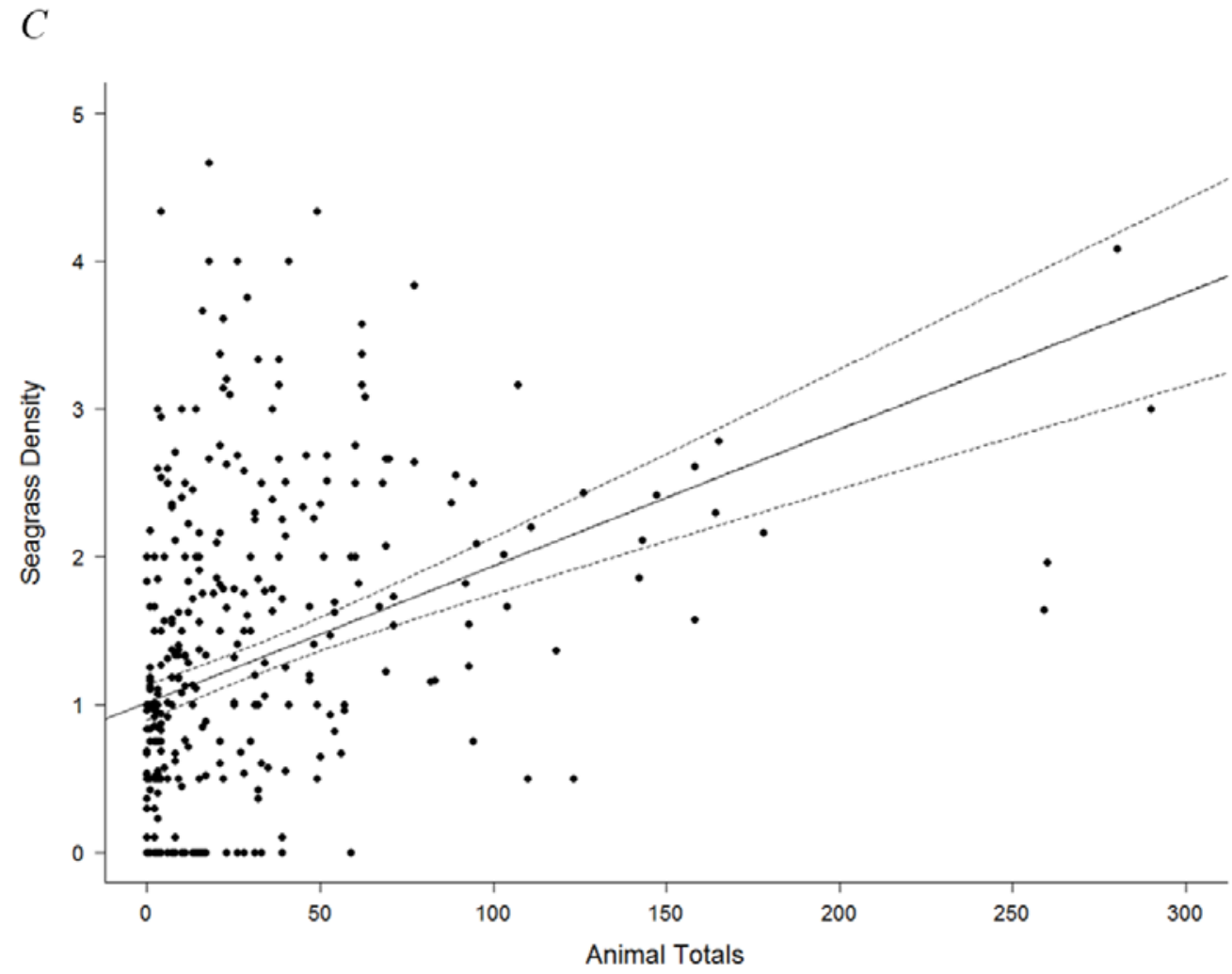

Figure 7. Kendall's tau correlation with $95 \%$ confidence intervals showing a negative correlation between $A$, turbidity (in nephelometric turbidity units [NTUs] and seagrass density; $B$, turbidity and combined totals of shrimps, fishes, and crabs; and $C$, a positive correlation between seagrass density and combined totals of shrimp, fishes, and crabs.

\section{$\mathrm{BACl}$}

Results from the BACI test helped to integrate changes in turbidity, seagrass density, and animal totals. Location explained most of the variation in the model, followed by year (table 3). Neither season nor any interaction between factors were significant at the $p<0.05$ level. This analysis confirms previous results that the POM had more total animals than NBB. 
Table 3. Permutational multivariate analysis of variance (PERMANOVA) test results of total numbers of caridean shrimp, penaeid shrimp, and fish by location, year, season, and interactions between factors for Faunal Monitoring in Response to Harbor Dredging (FMHD) data. Sources of variation in models, $\mathrm{df}=$ degrees of freedom, $\mathrm{SS}=$ sums of squares, MS=mean squares, Pseudo-F statistic, and $P($ perm $)=$ attained significance level. Results were considered significant at $P($ perm $)<0.05)$.

\begin{tabular}{|c|c|c|c|c|c|}
\hline Source & $d f$ & SS & $M S$ & Pseudo-F & $P($ perm $)$ \\
\hline Location & 1 & 33403 & 33403 & 28.238 & 0.001 \\
\hline Year & 2 & 12064 & 6032.2 & 5.0994 & 0.001 \\
\hline Season & 1 & 2164.5 & 2164.5 & 1.8298 & 0.145 \\
\hline Season*Location & 1 & 3059.8 & 3059.8 & 2.5866 & 0.069 \\
\hline Year*Season & 2 & 5034.8 & 2517.4 & 2.1281 & 0.081 \\
\hline Year*Location & 2 & 2434.9 & 1217.4 & 1.0292 & 0.373 \\
\hline Year*Season*Location & 2 & 2557.1 & 1278.6 & 1.0808 & 0.366 \\
\hline Residuals & 348 & 348 & $4.1166 \mathrm{E}+05$ & 1182.9 & \\
\hline Total & 359 & 359 & $4.7238 \mathrm{E}+05$ & & \\
\hline
\end{tabular}

PRIMER 7 was used to create a nonmetric multidimensional scaling diagram of community similarity at both sites through the three-year FMHD. The BACI Euclidean distance graph showed variability in NBB and POM throughout the study period and displays amount of similarity between both locations for each year (fig. 8). Before dredging began in 2014, NBB and POM were relatively similar to each other. Between 2014 and 2015, NBB remained similar to POM. Once the dredging commenced in 2015, POM became markedly variable compared with NBB and year centroids (fig. 8). By 2016, NBB and POM were dissimilar to the previous years but similar to each other. The resemblance of both locations by 2016 indicated a shift of community structure at both locations. 


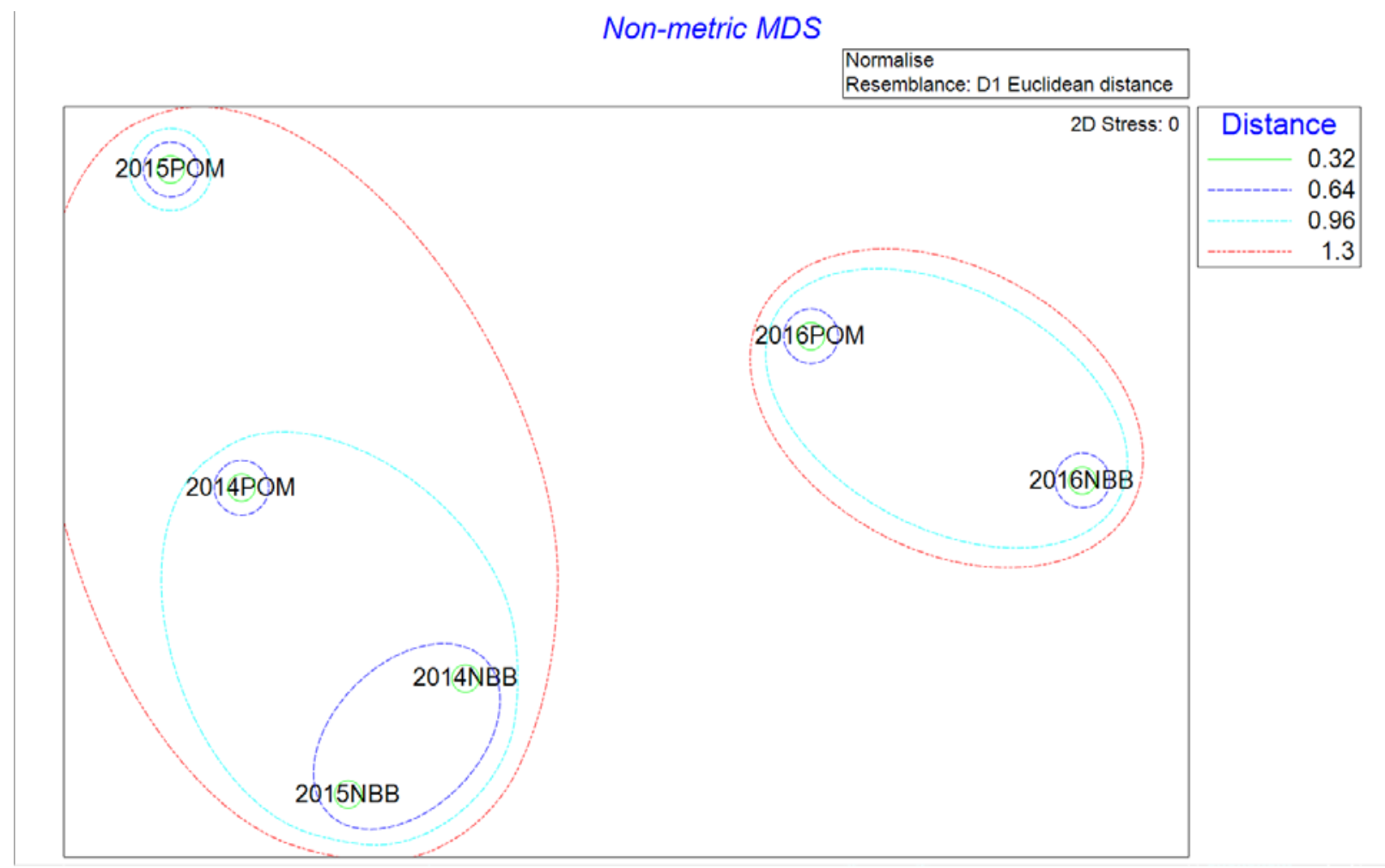

Figure 8. Nonmetric multidimensional scaling Euclidean distance graph created by using PRIMER 7. Graph visually depicts the resemblance of North Biscayne Bay (NBB) and Port of Miami (POM) community structures to each other through the years. 


\section{Discussion}

\section{Turbidity}

In addition to collecting epibenthic fauna and determining vegetation cover and abundance, the FMHD project recorded various environmental data. These data included salinity, temperature, turbidity, sediment depth, and water depth taken at each sampling site. These environmental factors can have a substantial effect on seagrass distribution and condition. For example, $H$. wrightii can tolerate extreme salinities and turbidity, whereas $T$. testudinum cannot (Fourqurean and others, 2001). These measurements can help determine if there are gradients across the bay that may explain changes in the distribution and density of seagrass (FMHD). Dredging can have adverse effects on the environment by increasing turbidity in the water column. Increased turbidity affects primary production as it reduces the amount of light that can penetrate the water column, which can lead to a reduction in photosynthesis and productivity (McCloskey and Unsworth, 2015).

Increased turbidity levels from dredging can directly and indirectly affect seagrass. Dredging increases the amount of suspended material in the water column, which reduces the light available to the submerged vegetation (Erftemeijer and Lewis, 2006). Both NBB and POM showed similar increases in turbidity over the course of the study. Marked differences in turbidity were observed at NBB among the years 2014 to 2016 and between 2015 and 2016 . During the fall of 2015, the northeastern corner of the bay began to experience a seagrass die-off which may have been the result of higher turbidity. However, in 2015, our data showed high turbidity values in areas of the bay where the die-off was not present. By 2016, average turbidity values had substantially increased throughout all sampling sites in the bay. This increase suggests that the die-off did not contribute to the observed turbidity increase among our sampling areas. However, because of the significant increase in turbidity values between 2015 and 2016, conclusions about the direct effects of dredging on NBB could not be made from this study. The increase in turbidity in the bay cannot be entirely attributed to the seagrass die-off or to adjacent dredging from the POM.

POM showed the same significant effects in turbidity as NBB. There was a significant increase between 2014 and 2016 and a significant increase between 2015 and 2016 after dredging occurred. There was no significant difference between 2014 and 2015 before dredging began. Average turbidity values by 2016 were significantly higher than the previous two years throughout the sampling sites. Fig. 9A-D displays the overall trend in turbidity throughout the three-year study period in FMHD compared with the seven-year FIAN record. In FIAN, average turbidity values in NBB were fairly constant, varying around a mean of 2.5 NTU, whereas turbidity in POM exhibited a decreasing trend (Robblee and Browder, written communication to USACE, USGS, and NOAA National Marine Fisheries Service).

\section{Seagrass Density}

Seagrass is an essential part of coastal communities in South Florida. Seagrass beds provide food and habitat and host numerous fishes, invertebrates, and other animals. Seagrass density was negatively correlated with turbidity. Higher turbidity values likely resulted in lower seagrass densities (Norland and Gullstrom, 2013). This relationship was observed in the same pattern as turbidity in the FMHD study. In NBB and POM, there was a significant difference between 2014 and 2016 and between 2015 and 2016 but not between 2014 and 2015. Fig. 10A- 
$D$ shows that both locations in the FIAN and FMHD studies had decreasing seagrass density trends over time. However, the FIAN study did not show significant decreases throughout the seven-year period. Both NBB and POM had more substantial decreases over the three years of the FMHD study than the seven previous years of the FIAN study. Seagrasses will need to recover to reverse the current downward trend.

Average seagrass densities were compared to the average turbidity for wet and dry seasons for NBB and POM. The highest peak turbidity observed for both locations during the FMHD study occurred during the dry season directly succeeding the dredging. Turbidity decreased while the average seagrass density showed little change. This suggests that the seagrass may need more time to recover from dredging operations and that continuing to monitor the bay is essential to understand the long-term effects of turbidity on seagrass. 


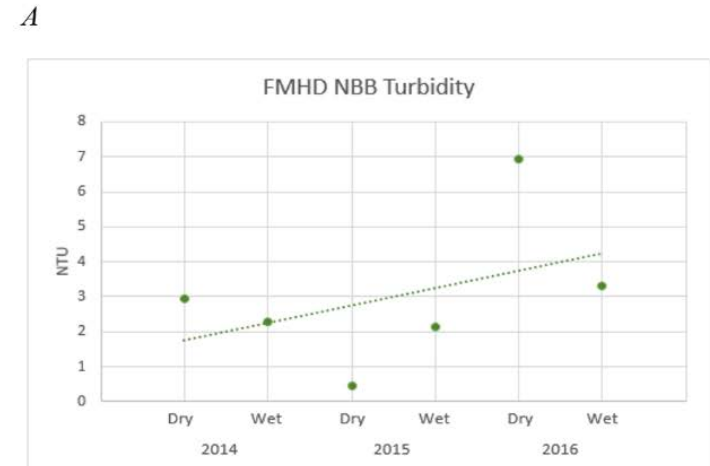

B

C

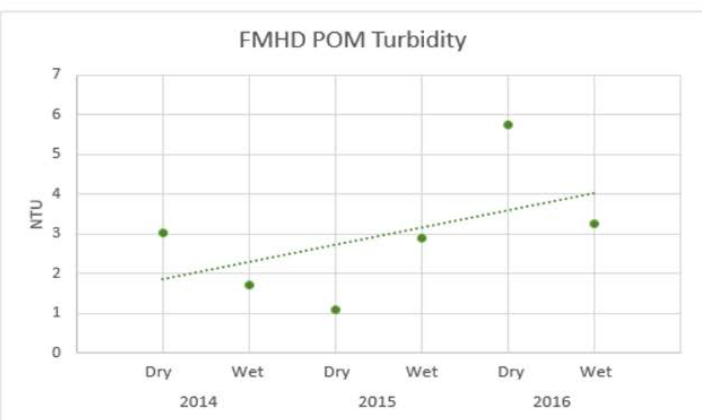

D
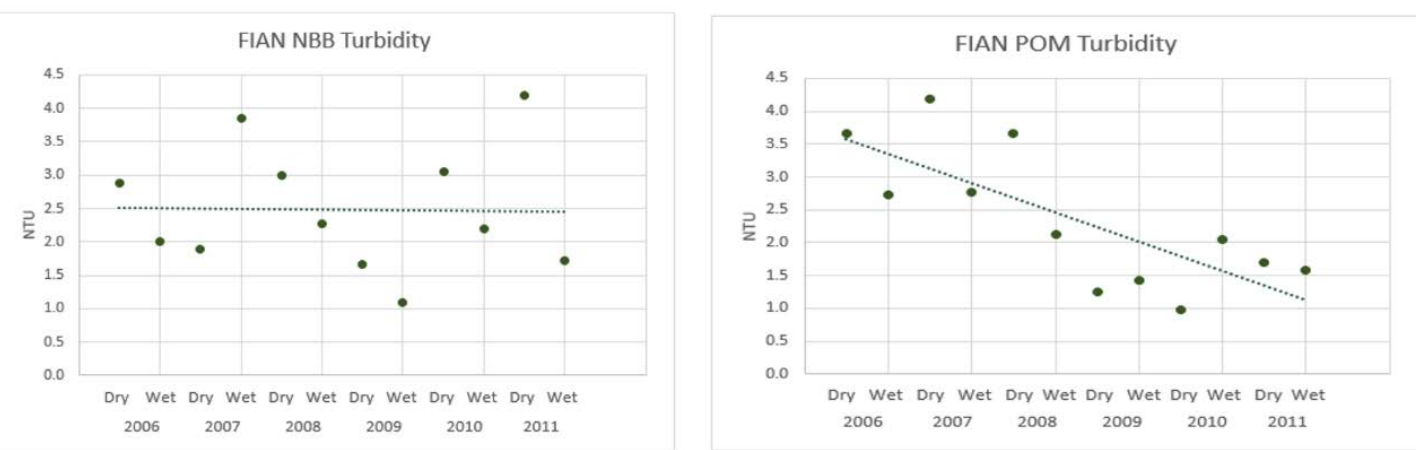

Figure 9. Average turbidities for North Biscayne Bay (NBB) and Port of Miami (POM) observed throughout the study period for the Faunal Monitoring in Response to Harbor Dredging (FMHD) and Fish and Invertebrate Assessment Network (FIAN) studies as a comparison of conditions before and after dredging. 
$A$

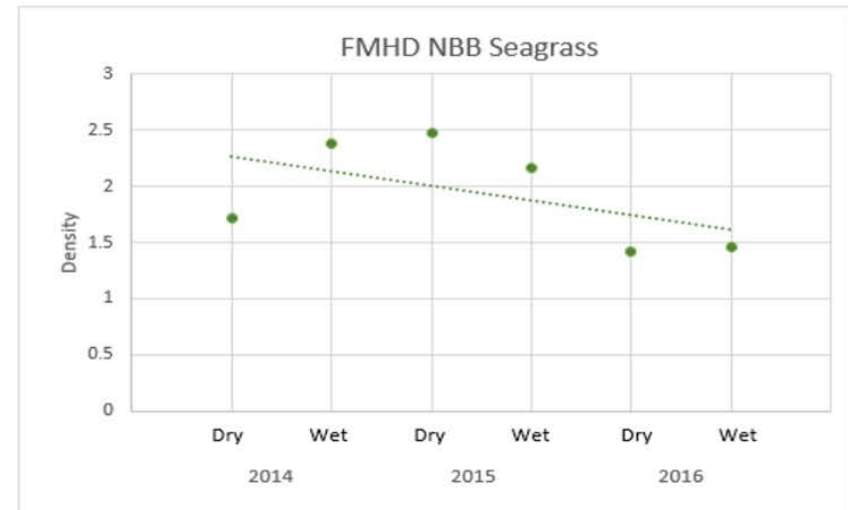

C

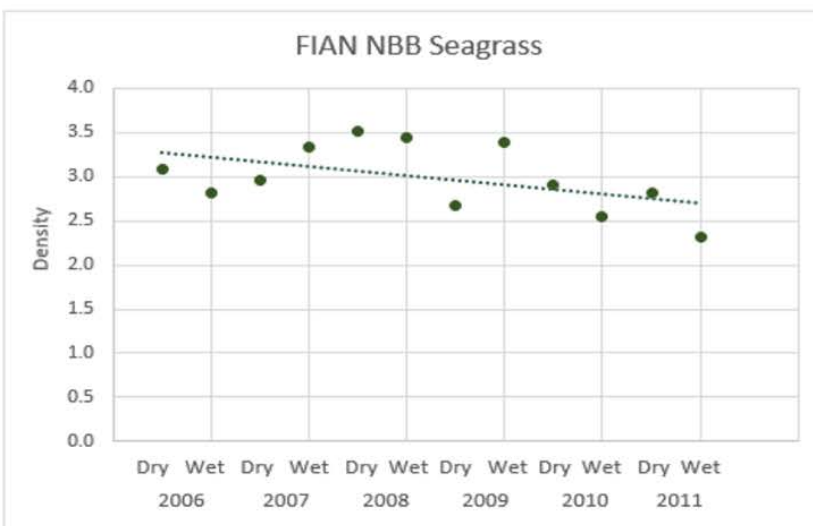

$B$

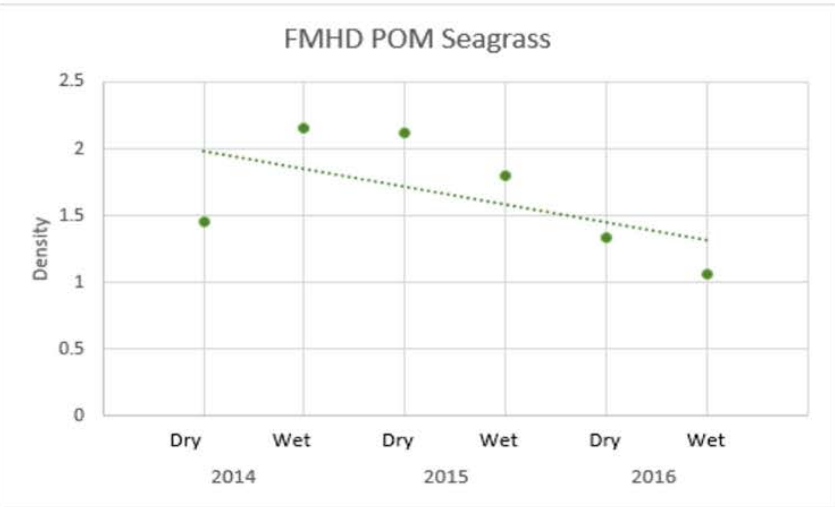

$D$

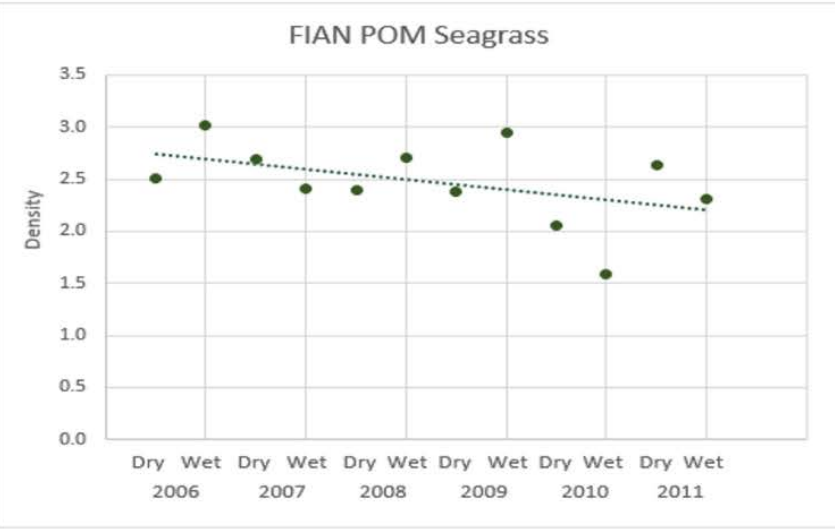

Figure 10. Average seagrass densities (as defined in table 1) for North Biscayne Bay (NBB) and Port of Miami (POM) observed throughout the study period for the Faunal Monitoring in Response to Harbor Dredging (FMHD) and Fish and Invertebrate Assessment Network (FIAN) studies as a comparison of conditions before and after dredging. 


\section{Animal Totals}

As in the FIAN study, seagrass fauna was collected and benthic vegetation was observed twice annually in NBB and POM. Community assemblages of fish and decapod invertebrates were determined using a throw-trap. Throw-trap collections are important to determine the effects of structural changes in the environment because of the important role of seagrass as habitat and food to marine animals. Changes in community structure as compared with those observed in the FIAN study were observed during 2014 and 2015, the first two years of the FMHD study, when dredging activities were taking place. Since vegetation is positively correlated to faunal abundance, dredging could affect animal populations and community assemblages that use seagrass as habitat.

Animal totals decreased significantly throughout the 3-year period for both locations (fig. $5 B$. Both NBB and POM had slight but significant decreases from year to year in caridean shrimp, penaeid shrimp, and fish totals. Unlike seagrasses, some animals have the ability to leave an area when conditions become unfavorable. Our research shows animal totals were negatively correlated to increased turbidity values. Because of dredging activities, it may be important to monitor faunal composition of the POM to determine whether these populations continue to decrease or recover. In this study, the POM had more significant decreases in animal totals than NBB which may have been due to dredging.

There were differences in the community structure in the fish and shrimp populations in both locations throughout the study period (fig. 6A-D). In NBB, populations of Floridichthys (pupfishes), Lucania (ray-finned killifishes), and Microgobius (gobies) decreased by approximately 80, 72, and 96 percent, respectively from the start of the project in 2014 to 2016. The Ctenogobius (gobies), Gobiosoma (gobies), and Hippocampus (pipefishes and seahorses) had overall increases of 92, 76, and 43 percent, respectively, throughout the project. In POM, Gobiosoma and Hippocampus populations remained relatively stable. Diplogrammus (dragonets) populations decreased by approximately 95 percent. Populations of both Floridichthys and Microgobius substantially declined. By 2016, Floridichthys and Microgobius were no longer present in our study areas (fig. 6A-B). Lucania was the only genus of fishes that showed a substantial population increase of 81 percent.

There were also notable changes in the caridean shrimp population in both sampled locations throughout the study period. Shrimp composition in NBB consisted mostly of Thor and Hippolyte, both of which belong to the family Hippolytidae. There was a large shift between the two genera: Thor decreased, and Hippolyte became the major genus found from 2014 to 2016 . Although Hippolyte became the dominating genus, it still experienced declines. Overall, Hippolyte and Palaemonetes suffered severe decreases of 95 and 100 percent by 2016. In POM, the shrimp community was more variable than in NBB. The major genera that made up the population were Alpheus, Hippolyte, Thor, and Periclimenes. There were more genera affected than in NBB with decreases of 61, 48, 60, 30, and 86 percent in Alpheus, Hippolyte, Latreutes, Periclimenes, and Processa, respectively. The only genus that exhibited a major increase was Thor, with an overall increase in population of approximately 74 percent from 2014 to 2016. The number of penaeid shrimps collected from 2014 to 2016 declined by approximately 61 percent throughout the study period (fig. 6C-D).

Monitoring the faunal composition in response to environment-altering activities improves understanding of ecosystem function. Some species may show resilience when detrimental changes have been made to their environment while others do not, which was observed in several genera of fishes and shrimp in NBB and POM. Those species that are not 
tolerant to these changes may disappear from the area. In this study, there were two fish and one shrimp genera that were observed in 2014 that declined throughout the study period and were not observed by 2016.

Unfortunately, there were no collections in 2017. There could have been a return to previous states in both locations or conditions may have continued to decrease seagrass and animal totals. It is possible that the populations we observed decreasing or disappearing completely, could have rebounded by 2017. Without further sampling, it is unknown whether the dredging could have lasting effects on the seagrass community.

\section{Selected References}

Behringer, D.C., and Butler, M.J., IV, 2006, Stable isotope analysis of production and trophic relationships in a tropical marine hard-bottom community: Oecologia v. 148, p. 334-341. Braun-Blanquet, J., 1965, Plant Sociology: The study of plant communities: London, Hafner. d'Avack, E.A.S., Tillin, H., Jackson, E.L. and Tyler-Walters, H. 2014. Assessing the sensitivity of seagrass bed biotopes to pressures associated with marine activities. JNCC Report No. 505. Peterborough, Joint Nature Conservation Committee.

Erftemeijer, P.L.A., and Lewis, R.R.R, III, 2006, Environmental impacts of dredging on seagrasses: A review: Marine Pollution Bulletin v. 52, p. 1553-1572.

Essink, K., 1999, Ecological effects of dumping of dredged sediments; options for management: Journal of Coastal Conservation, v. 5, p. 69-80.

Fourqurean, J.W., Willsie, A., Rose, C.D., and Rutten, L.M., 2001, Spatial and temporal pattern in seagrass community composition and productivity in south Florida:Marine Biology v. 138, p. 341-354.

Fuentes M.P.B., Lawler I.R., Gyuris E., 2006, Dietary preferences of juvenile green turtles (Chelonia mydas) on a tropical reef flat: Wildlife Research, v. 33, p. 671-678. doi:10.1071/WR05081.

Green E.P. and Short F.T., 2003, World atlas of seagrass: Berkeley, Calif., University of California Press Berkeley.

Hallermeier, R.J., 1981, Terminal settling velocity of commonly occurring sand grains: Sedimentology, v. 28, no. 6, p. 859-865.

Johnson, B., 2011, Port Miami 2035 Master Plan Executive Summary: http://www.miamidade.gov/portmiami/master-plan.asp.

Koch, E.W., 2001, Beyond light: Physical, geological, and geochemical parameters as possible submersed aquatic vegetation habitat requirements: Estuaries, v. 24, no. 1, p. 1-17.

Komar, P.D., and Miller, M.C., 1973, The threshold of sediment movement under oscillatory water waves: Journal of Sedimentary Petrology, v. 43, no. 4, p. 1101-1110.

Komar, P.D., and Miller, M.C., 1975, On the comparison between the threshold of sediment motion under waves and unidirectional currents with a discussion of the practical evaluation of the threshold: Journal of Sedimentary Petrology, v. 45, no. 2, p. 362-367.

Littler, D.S., Littler, M.M., Bucher, E.B., and Norris, J.N., 1989, Marine plants of the Caribbean: A field guide from Florida to Brazil: Washington, D.C., Smithsonian Institution Press.

Lohrer, A.M., and Wetz, J.J., 2003, Dredging-induced nutrient release from sediments to the water column in a southeastern saltmarsh tidal creek: Marine Pollution Bulletin, v. 46, p. 1156-1163.

McCloskey, R., and Unsworth, R., 2015, Decreasing seagrass density negatively influences associated fauna: Peer J, doi: 10.7717/peerj.1053. 
Moore, K.A.; Wetzel, R.L., and Orth, R.J., 1997, Seasonal pulses of turbidity and their relations to eelgrass (Zostera marina L.) survival in an estuary: Journal of Experimental Marine Biology and Ecology, v. 215, no. 1, p. 115-134.

Norlund, L. M., and Gullstrom, M., 2013, Biodiversity loss in seagrass meadows due to local invertebrate fisheries and harbor activities: Estuarine, Coastal and Shelf Science, v. 135, no. 0, 231-240.

Onuf, C.P., 1994. Seagrasses, dredging and light in Laguna Madre, Texas, U.S.A.: Estuarine, Coastal and Shelf Science, v. 39, no. 1, p. 75-91.

Pennekamp, J.G.S., Epskamp, R.J.C., Rosenbrand, W.F., Millie, A., Wessel, G.L., Arts, T., and Deibel, I.K., 1996, Turbidity caused by dredging; viewed in perspective: Terra et Aqua, v. 64, p. 10-17.

Perkey, D., Pratt, T.C., and Ganesh, N.B., 2010, Comparison of SSC measurements with acoustic backscatter data: West bay sediment diversion, Mississippi River: Las Vegas, Nev., Proceedings of the 2nd Joint Federal Interagency Conference.

Ralph, P.J., Tomasko, D., Moore, K., Seddon, S., and Macinnis-Ng, C.M.O., 2006, Human impacts on seagrasses: Eutrophication, sedimentation, and contamination, in Larkum, A.W.D., Orth, R.J., and Duarte, C., editors, Seagrasses: Biology, ecology and conservation: Dordrecht, The Netherland, Springer, p. 567-593.

RECOVER., 2004, CERP Monitoring and Assessment Plan. Part I. Monitoring and Supporting Research. Comprehensive Ecosystem Restoration Project: West Palm Beach, Fla., South Florida Water Management District, and Jacksonville, Fla., U.S. Army Corps of Engineers. Robert, J.O., Matthew, C.H., and Graeme, J.I., 2006, Ecology of seagrass seeds and seagrass dispersal processes, in Larkum, A.W.D., Orth, R.J., and Duarte, C., editors, Seagrasses: Biology, ecology and conservation: Dordrecht, The Netherlands, Springer, pp. 111-133.

Sabol, B., and Shafer, D., 2005, Dredging effects on seagrasses: case studies from New England and Florida: Western Dredging Association 25th Annual WEDA conference, p. 335-346.

Schlacher-Hoenlinger, M.A., and Schlacher, T.A., 1998, Differential accumulation patterns of heavy metals among dominant macrophytes of a Mediterranean seagrass meadow: Chemosphere, v. 37, no. 8, p. 1511-1519.

Schoellhamer, D.H., 1996, Anthropogenic sediment resuspension mechanisms in a shallow microtidal estuary: Estuarine, Coastal and Shelf Science, v. 43, no. 5, 533-548.

Schoellhamer, D.H., 2002, Comparison of the basin-scale effect of dredging operations and natural estuarine processes on suspended sediment concentration: Estuaries, v. 25, no. 3, p. 488-495.

Serafy, J. E., Lindeman, K. C., Hopkins, T. E., and Ault, J. S., 1997, Effects of freshwater canal discharge on fish assemblages in a subtropical bay; field and laboratory observations: Marine Ecology Progress Series, v. 160, p. 161-172.

Shafer, D.J., 1999, The effects of dock shading on the seagrass Halodule wrightii in Perdido Bay, Alabama: Estuaries, v. 22, no. 4, p. 936-943.

Short, F., Carruthers T., Dennison, W. and Waycott, M., 2007, Global seagrass distribution and diversity: A bioregional model: Journal of Experimental Marine Biology and Ecology, v. 1 and 2, p. 3-20.

Short, F., and Wyllie-Echeverria, S., 1996, Natural and human- induced disturbances of seagrasses: Environmental Conservation, v. 23, no. 1, p. 17-27

Smith, E. P., 2002, Before-after-control-impact design, in Encyclopedia of environmetrics: John Wiley and Sons. 
Smith, E.P., Orvos, D. R., and Cairns, J., Jr, 1993, Impact assessment using the before-aftercontrol impact (BACI) model; concerns and comments: Canadian Journal of Fisheries and Aquatic Sciences, v. 50, no. 3, 627-637.

Soulsby, R., 1997, Dynamics of marine sands: London, Thomas Telford, 272 p.

U.S. Army Corps of Engineers, n.d., Miami harbor deepening: accessed March 19, 2018 at http://www.saj.usace.army.mil/Missions/Civil-Works/Navigation/Navigation-Projects/MiamiHarbor-Deepening/.

U.S. Geological Survey, 2004, Changing salinity patterns in Biscayne Bay, Florida: U.S. Geological Survey Fact Sheet 2004-3108, not paginated.

Wang, P., and Beck, T.M., 2012, Morphodynamics of an anthropogenically altered dual-inlet system: John’s Pass and Blind Pass, westcentral Florida, USA: Marine Geology, v. 291-294, p. 162-175, http://dx.doi.org/10.1016/j.margeo.2011.06.001.

Wang, P., and Stone, G.W., 2004, Nearshore wave measurement, in. Schwartz, M., editor, Encyclopedia of Coastal Science: Dordrecht, The Netherlands, Springer, p. 869-874.

Zieman, J., Fourqurean, J., and Frankovich, T., 1999, Seagrass die-off in Florida Bay: Long-term trends in abundance and growth of turtle grass, Thalassia testudinum: Estuaries, v. 22, p. 460470.

Zieman, J., Fourqurean, J., and Iverson, R., 1989, Distribution, abundance and productivity of seagrasses and macroalgae in Florida Bay: Bulletin of Marine Science, v. 44, no. 1, p. 292-311. 